INSIGHTS INTO REGIONAL DEVELOPMENT

ISSN 2669-0195 (online) http://jssidoi.org/IRD/

2021 Volume 3 Number 2 (June)

http://doi.org/10.9770/IRD.2021.3.2(5)

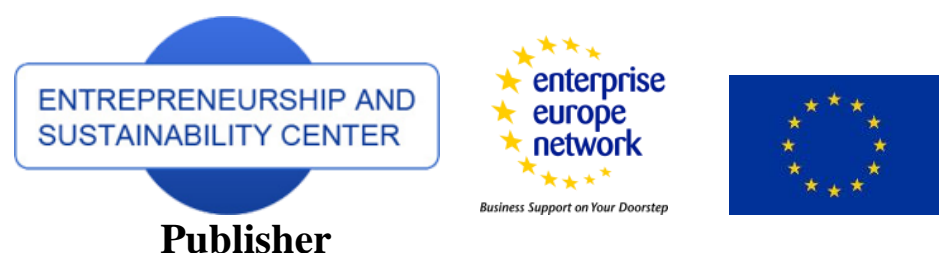

http://jssidoi.org/esc/home

\title{
POLITICAL STABILITY AND ECONOMIC GROWTH IN DEVELOPING ECONOMIES: LESSONS FROM MOROCCO, TUNISIA, AND EGYPT TEN YEARS AFTER THE ARAB SPRING
}

\author{
Nizar Becheikh \\ The American University in Cairo, School of Business, AUC Avenue, P.O. Box 74, New Cairo 11835, Egypt \\ E-mail: $\underline{\text { nbecheikh@aucegypt.edu }}$
}

Received 25 January 2021; accepted 10 March 2021; published 30 June 2021

\begin{abstract}
In 2011, the Arab region has seen an unprecedented popular uprising commonly referred to as the "Arab Spring". The objective of this paper is to analyze the economic performance and institutional changes that have taken place in Egypt, Tunisia, and Morocco following the Arab Spring, and understand the interconnect between the socio-political context on the one side, and economic performance and growth on the other side, in a period marked by severe turbulences, especially in Tunisia and Egypt. The analysis covers the economic, institutional, competitiveness, business environment, infrastructural, and human capital aspects in the three countries. It is based on the author's own research and knowledge of the region, the recent emerging literature on the topic, newspaper archives, and the publicly available economic and business data and reports provided by international organizations. Our analysis shows that Tunisia, the country that has ignited the Arab Spring, was the one most hit by its aftermath on the economic, social, and institutional levels. We argue that, although pure authoritarian regimes were historically a failure in the region, "Western" democracy has so far shown several limits when applied into the Arab region context as it led to neither socio-political stability nor economic growth.
\end{abstract}

Keywords: economic growth; institutions; political stability; Arab Spring; Egypt; Morocco; Tunisia; Political Economy

Reference to this paper should be made as follows: Becheikh, N. 2021. Political stability and economic growth in developing economies: lessons from Morocco, Tunisia and Egypt ten years after the Arab Spring. Insights into Regional Development, 3(2), $229-251$. http://doi.org/10.9770/IRD.2021.3.2(5)

JEL Classifications: E02, P48

Additional disciplines: political science

\section{Introduction}

Friday, December 17, 2010, 11:30 am (local time), a 26-year-old Tunisian street vendor named Mohamed Bouazizi doused himself with gasoline and set himself alight with a match. Bouazizi was in total despair after years of hopeless trials to make a decent living, which led him to get into debt to buy a small wheelbarrow and use it to sell fruits and vegetables in the streets of Sidi Bouzid, an inland impoverished city located some 260 kilometers away from Tunis, the capital city. With no vending permit, and no money to bribe the police officials to allow him continue his small business, he saw his cart confiscated by a municipal officer who was reported to have publicly spat at him and slapped him in the face. Outraged, Bouazizi put himself in fire to die a couple of 


\section{INSIGHTS INTO REGIONAL DEVELOPMENT}

ISSN 2669-0195 (online) http://jssidoi.org/jesi/

2021 Volume 3 Number 2 (June)

http://doi.org/10.9770/IRD.2021.3.2(5)

weeks later by succumbing to his burns. His sister described his death as a "rebellion against insult" pushed by "oppression, injustice, and despotism" (Coşkun, 2019; Pearlman, 2013).

Bouazizi's self-immolation ignited a country-wide uprising, known as the "Jasmin revolution", that pushed thenPresident, Zine El Abidine Ben Ali, to step down and flee the country on January 14, 2011. Tunisians celebrated their "victory", and overnight started looking forward to the future with eyes full of confidence and optimism. They were confident that the upcoming years will bring them "jobs", "freedom", and "dignity", the slogans they had vigorously voiced during the two weeks of massive protests.

The popular upheaval moved soon to Egypt, where millions of people went into the street on January 25, in Tahrir square and all over the country, calling for the end of the Mubarak regime that had ruled the country for almost thirty years. Their claims were: "bread", "freedom", and "social justice" reflecting the economic and social hardships that Egypt was enduring (Mabon, 2013). Unable to contain the enormous popular uprising, Hosni Mubarak resigned on February 11 as President of Egypt.

Popular protests expanded in a domino effect to other countries in the region such as Libya, Yemen, Syria, Bahrain, and others, leading to what is commonly referred to as the "Arab Spring". The claims in all countries were the same: unseating the autocratic rulers that have been in power for decades, combatting rampant corruption, favoritism, and repression, and instituting democratic regimes reflecting a social contract based on economic inclusiveness, social justice, and the respect of the people and their rights (Acemoglu et al., 2018; Kienle, 2012).

Ten years later, different scenarios have taken place in the region. Syria, Libya, and Yemen witnessed a gloomy fate, as these countries entered into civil wars that were made difficult to end with the involvement of external parties supporting one side or the other of the conflict. Tunisia and Egypt have been spared this dramatic scenario. Despite the multiple episodes of instability, both countries ensured a relatively smoother transition, avoiding armed conflicts and ensuring the continuity of the State and its institutions.

Amidst these conflictual events, Morocco was one of the countries in the region that succeeded in maintaining order by absorbing the relatively modest social uprising led by the February 20 Movement (F20M) (Burger et al., 2013; Campante and Chor, 2012; Costello et al., 2015). King Mohamed VI, whose reign started in July 1999, had swiftly accommodated pressures of the furious crowd for more inclusive political, economic, and social reforms, which was deemed sufficient by the people as basis for activating the debate with the opposition for further renegotiations of the existing social contract (El-Haddad, 2020). The reforms implemented entailed continuity rather than radical changes though (Bergh and Rossi-Doria, 2015; Kienle, 2012; Looney, 2014). Morocco has thus been spared the political struggle that Egypt and Tunisia endured over the last decade.

The objective of this paper is to provide a holistic review of the three economies with a specific focus on the evolution of the macroeconomic and competitiveness parameters as well as the business and institutional environment over the last decade. Our aim is to understand the impact the Arab Spring had on the three economies, and analyze the interlocking ring between the socio-political context on the one side, and economic performance and growth on the other side, in a period marked by severe turbulences, especially in Tunisia and Egypt. The analysis is based on the author's own research and knowledge of the region, the recent emerging literature on the topic, newspaper archives, and the publicly available economic and business data and reports provided by international organizations.

The remainder of this paper is organized as follows. We first review the post-Arab Spring economic performance in the three countries (section 2). Section 3 follows with the analysis of competitiveness, innovation, and business environment developments. Section 4 reviews next the evolution of the infrastructure and human capital aspects. 


\section{INSIGHTS INTO REGIONAL DEVELOPMENT}

ISSN 2669-0195 (online) http://jssidoi.org/jesi/

2021 Volume 3 Number 2 (June)

http://doi.org/10.9770/IRD.2021.3.2(5)

We then discuss the parallel between the socio-political context and economic performance in section 5, before ending with the main conclusions with regards to the decade-long impact the Arab Spring had on the three economies.

\section{Economic Performance and Growth}

Economic performance and growth followed different trajectories in the three countries. Post-revolution Tunisia has reported an overall negative economic performance translating into a Gross Domestic Product (GDP) (Fig.1) and GDP per capita (Fig. 2) decline throughout the decade. In the years preceding the revolution, and despite the serious flaws pertaining mainly to corruption, high unemployment, and unequal regional development, the World Economic Forum (WEF) repeatedly ranked Tunisia as the most competitive economy in Africa, and the World Bank (WB) as well as the International Monetary Fund (IMF) heralded Tunisia as a role model for other developing countries (Rijkers et al., 2017; World Bank, 2014). Ten years after the revolution, the Tunisian government is still struggling to boost economic growth and alleviate the negative effect the Arab Spring had on the aggregate economy (Matta et al., 2019).

The repeated terrorist attacks, political assassinations, and endless labor strikes have been a drag on the economy. Foreign Direct Investments (FDIs), despite a rebound in 2012, have consistently regressed over the years to amount \$0.99bn in 2018, down from \$1.33bn in 2010 (Fig. 3). International Tourism Receipts (ITR) have fallen from $\$ 3.5 \mathrm{bn}$ in 2010 to $\$ 1.7 \mathrm{bn}$ in 2016, before recovering to $\$ 2.3 \mathrm{bn}$ in 2018 (Fig. 4). Phosphates production, which was about 8 million tons in 2010, dropped to 2.5 million tons in 2011 (AfDB 2012), and has not recovered since then. Labor strikes, social protests, and the 21,000 new employees hired, many of them believed to be ghost jobs, have caused a loss of almost \$1bn a year since 2011 to Compagnie des Phosphates de Gafsa, the stateowned phosphates producer, which had been providing Tunisia with $10 \%$ of its total exports, and are driving it to bankruptcy (Ghanmi, 2019; Serrano, 2019). Most other State-owned enterprises have suffered the same fate (Brockmeyer et al., 2015; Raballand et al., 2015).

Unemployment soared from $13.05 \%$ in 2010 to $18.33 \%$ in 2011, before falling gradually to $15.51 \%$ in 2019 (Fig. 5). The massive recourse to international debt has dramatically increased the external debt ratio which reached a critical 90\% of the Gross National Income (GNI) in 2018 (Fig. 6). In 2018, the Tunisian dinar (TND) was traded at almost the double of its 2009 exchange rate to the USD (Fig. 7).

Most of the externally contracted debt was directed to finance the outrageously increasing government spending which reached $20.5 \%$ of the GDP in 2019, up from 16.6\% in 2010 (Source: https://bit.ly/3tiKdz4). This increase is mainly attributable to the massive expansion of the wage bill in the wake of the revolution to reward supporters, honor the sharp rise in public sector hiring, and finance the multiple revisions of unionized public sector employees' wages (El-Haddad, 2020; Matta et al., 2019). In 2011 and 2012, around 95,000 new employees joined the public sector, versus 18,000 hired in 2010. The massive non-competitive recruitment, along with automatic promotions and salary raises, caused a degradation of competencies and a $44 \%$ increase in the wage bill between 2010 and 2014, compared to 28\% increase between 2006 and 2009 (Brockmeyer et al., 2015). Moreover, the increased investment in the military to combat terrorism and maintain order put another strain on the public finances (Serrano, 2019). 
INSIGHTS INTO REGIONAL DEVELOPMENT

ISSN 2669-0195 (online) http://jssidoi.org/jesi/

2021 Volume 3 Number 2 (June)

http://doi.org/10.9770/IRD.2021.3.2(5)

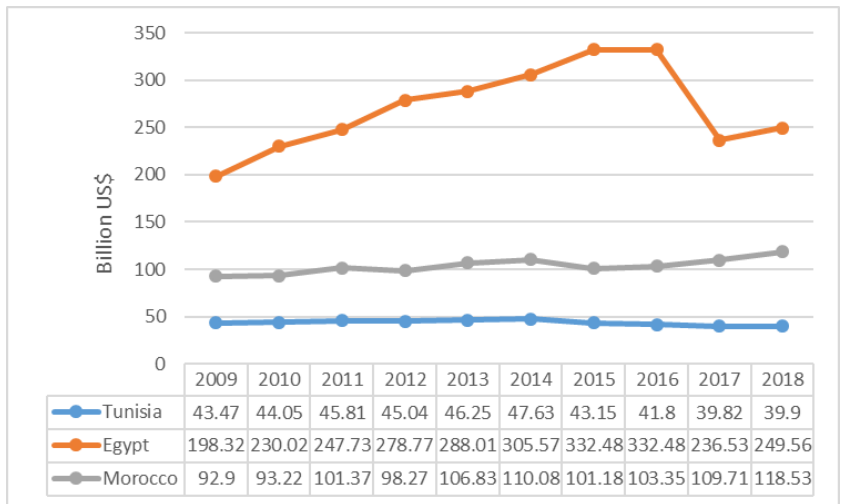

Fig 1. Gross Domestic Product (current prices)

Source: Own elaboration based on data retrieved from www.statistica.com

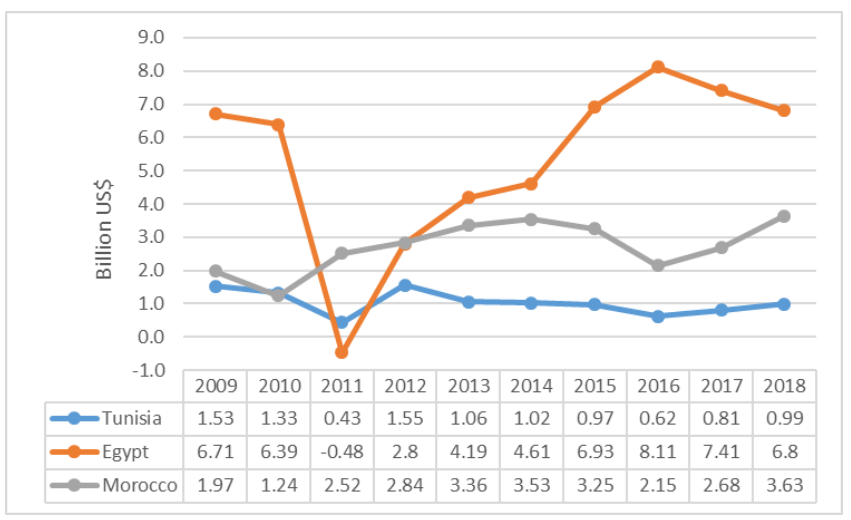

Fig 3. Foreign Direct Investment

Source: Own elaboration based on data retrieved from www.theglobaleconomy.com

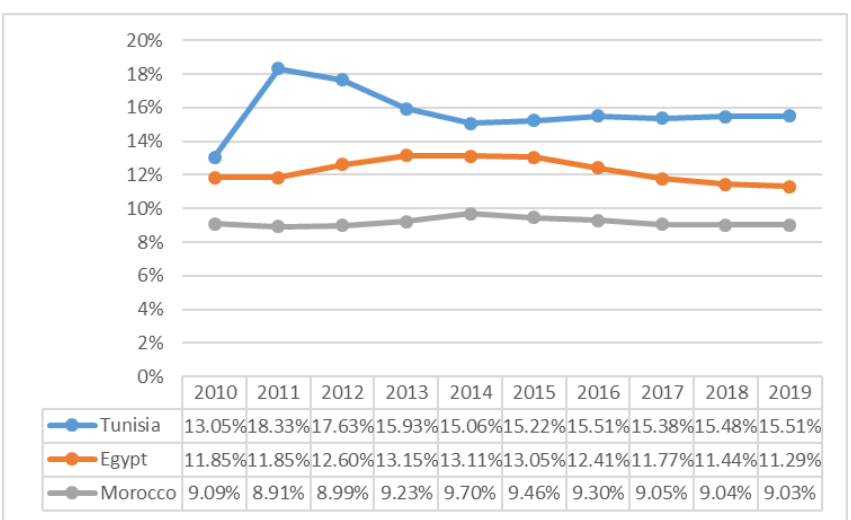

Fig 5. Unemployment rate

Source: Own elaboration based on data retrieved from www.statistica.com

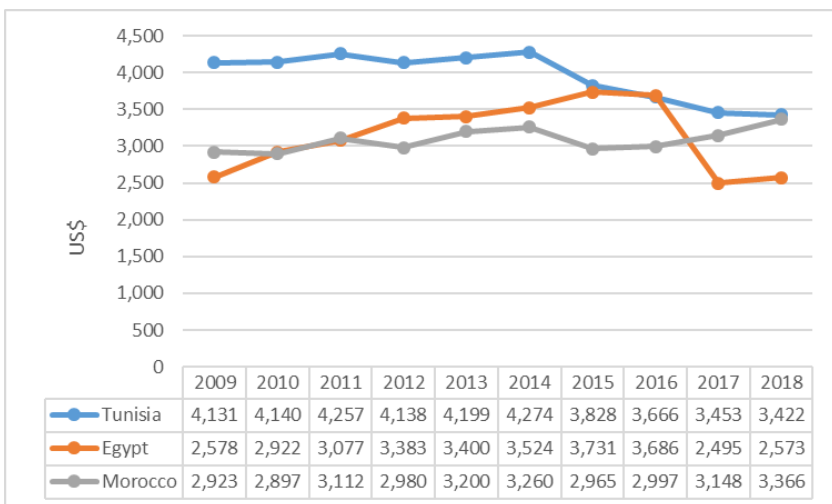

Fig 2. GDP per capita (current prices)

Source: Own elaboration based on data retrieved from www.statistica.com

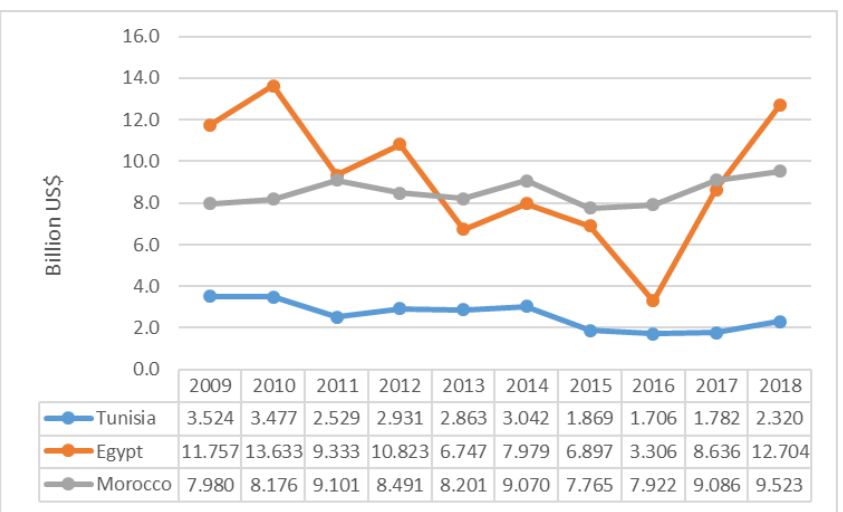

Fig 4. International tourism receipts

Source: Own elaboration based on data retrieved from https://data.worldbank.org

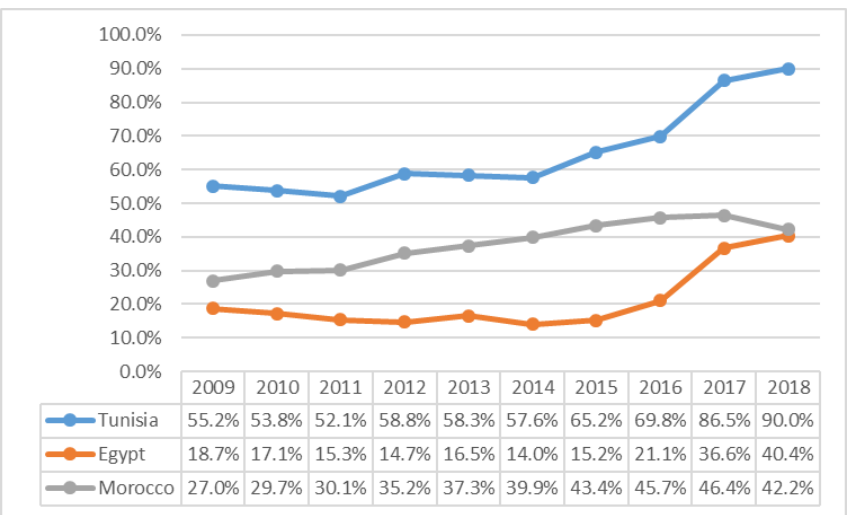

Fig 6. External debt as percent of GNI

Source: Own elaboration based on data retrieved from www.theglobaleconomy.com 
INSIGHTS INTO REGIONAL DEVELOPMENT

ISSN 2669-0195 (online) http://jssidoi.org/jesi/

2021 Volume 3 Number 2 (June)

http://doi.org/10.9770/IRD.2021.3.2(5)

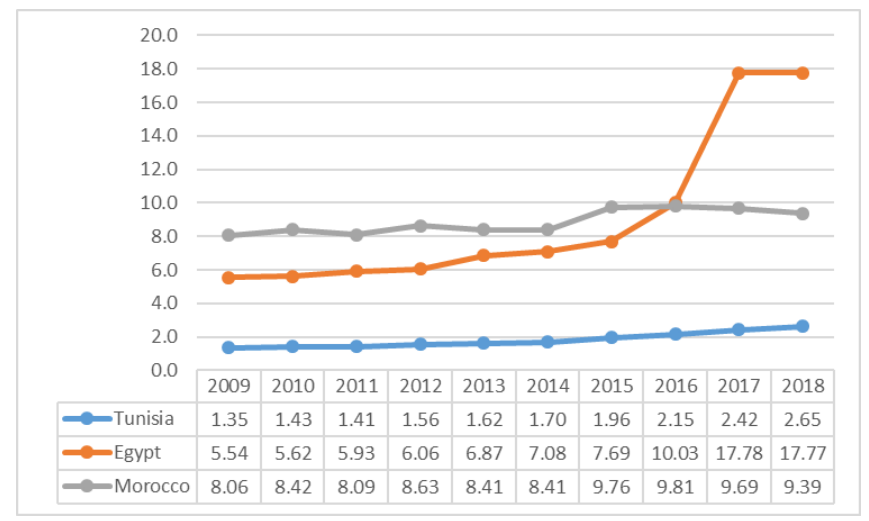

Fig 7. Exchange rate: local currency units per US\$ Source: Own elaboration based on data retrieved from www.theglobaleconomy.com

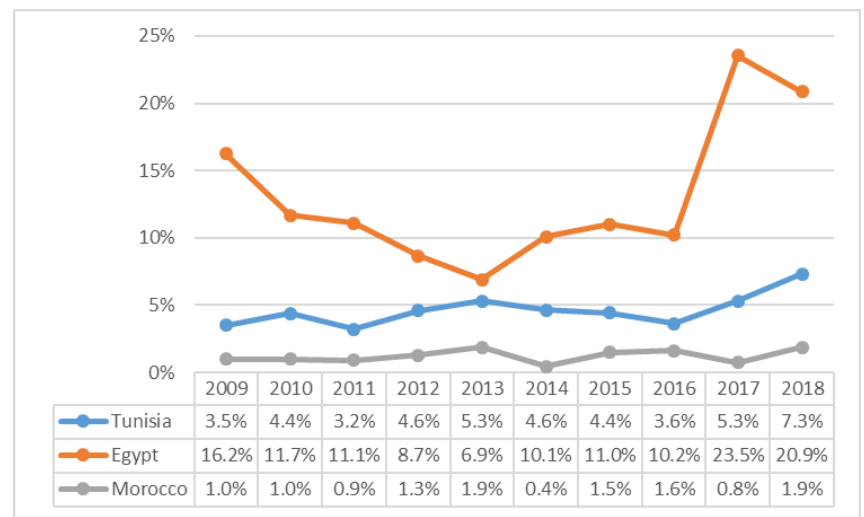

Fig 8. Inflation rate

Source: Own elaboration based on data retrieved from www.statistica.com

In Egypt, January 25 $5^{\text {th }}$ (Jan25) revolution had an immediate drastic effect on the FDIs. Year 2011 saw the investors fleeing the country which resulted in a negative net FDI of $\$ 0.48 \mathrm{bn}$ (net outflow) down from $\$ 6.39 \mathrm{bn}$ inflows in 2010. The numbers have quickly recovered though, peaking at $\$ 8.11 \mathrm{bn}$ in 2016. ITRs have dropped dramatically from $\$ 13.6 \mathrm{bn}$ in 2010 to a low of $\$ 3.3 \mathrm{bn}$ in 2016 , before rising again to $\$ 12.7 \mathrm{bn}$ in 2018 . November $3^{\text {rd }}, 2016$ marked a turning point in the post-revolution Egyptian economy. In an attempt to stabilize the economy and increase the foreign currency inflows which were severely affected by, among others, a significantly continual increase in the trade balance deficit since 2010, and to meet one of the key demands of the IMF to secure a \$12bn loan, the Central Bank of Egypt decided to float the Egyptian Pound (EGP). Overnight, the exchange rate of the EGP to the USD passed from 8.8 to 15.3 , to further rise to more than EGP18/USD by January 2017.

While this decision considerably improved the trade balance deficit, it led to a severe inflation that was exacerbated by the government decision to introduce new taxes and cut energy subsidies. Inflation soared from $10.2 \%$ in 2016, which was below 2010 levels (11.7\%), to a critical high of 23.5\% in 2017; a level that had not been seen in a generation (Fig. 8). On the positive side, the floating of the EGP has revived the tourism sector, which with the mega infrastructure, energy, and technology projects initiated by the government, helped in bringing the rising unemployment back to the pre-revolution levels. The recent years have seen the Egyptian economy getting slowly back to positive economic growth and performance. The level of external debt remains a source of concern though, as the ratio of external debt to GNI jumped from 17.1\% in 2010 to $40.4 \%$ in 2018 ; an increase of $136 \%$.

Morocco sustained the most regular GDP growth following the Arab Spring. Morocco's GDP rose to \$118.53bn in 2018 up from \$93.22bn in 2010; a 27\% increase. This reflected on the Moroccan Dirham which, despite a slight depreciation, has maintained a relatively stable exchange rate fluctuation to the USD compared to the TND and the EGP. Morocco has posted a modest increase of $16 \%$ in its ITR which grew from $\$ 8.2 \mathrm{bn}$ in 2010 to $\$ 9.5 \mathrm{bn}$ in 2018. In 2018, the FDIs rocketed to $\$ 3.63 \mathrm{bn}$ up from $\$ 1.24 \mathrm{bn}$ in 2010, an increase of 193\%. Despite cutting subsidies for some energy products in late 2014, Morocco succeeded in maintaining inflation at less than $2 \%$. This relatively positive economic performance did not help in improving employment though; even though the unemployment rate remains the lowest among the three countries (9.03\% in 2019) and has been maintained stable during the post Arab Spring years. Similar to Egypt and Tunisia, Morocco relied heavily on foreign debt, which led to an increased ratio of external debt to GNI from $29.7 \%$ in 2010 to $42.2 \%$ in 2018. 


\section{INSIGHTS INTO REGIONAL DEVELOPMENT}

ISSN 2669-0195 (online) http://jssidoi.org/jesi/

2021 Volume 3 Number 2 (June)

http://doi.org/10.9770/IRD.2021.3.2(5)

A crucial aspect in assessing economic prosperity is the distribution of wealth. The Gini index is commonly used as a gauge of economic inequalities among a population, with higher coefficients showing higher inequalities. The available data show a Gini index of 30.2\% and 35.8\% in Egypt and Tunisia, respectively, in 2010, and 39.5\% in Morocco in 2013 (Source: data.worldbank.org/indicator/SI.POV.GINI). In 2020, Egypt, Tunisia, and Morocco posted Gini coefficients of 31.8\%, 40\%, and 40.9\%, respectively (Source: Gini Coefficient by Country Population (2020-02-17). Retrieved from worldpopulationreview.com). These figures show that a decade later, the Arab Spring pushed the Gini coefficients upward in the three countries, reflecting higher inequalities.

Contrary to Egypt, Tunisia has failed to maintain a wealth distribution comparable to 2010, although the share dedicated to regional development in the public budget quadrupled after the revolution (Turki and Verdeil, 2015). The reasons for this unexpected outcome are multiple: the economic downturn, bureaucratic bottlenecks preventing the efficient spending of regional development budgets, but also rising corruption (I Watch, 2016; Matta et al., 2019), and the reckless increase of labor strikes which affected the competitiveness of the economy and further weakened the public finances that constitute the tool for wealth redistribution (Baccouche, 2016). Moreover, the convoluted semi-presidential political system that the 2014 constitution instituted bestows the power to three Presidents: President of the Republic, President of the Parliament, and President of the Government, which turned to be an obstacle to efficient governmental action and has repeatedly contributed to political stalemates (Mekki, 2018). In Morocco, inequalities have increased in both urban and rural areas (Loonley, 2014), and remain in 2020 at levels higher than Tunisia's and Egypt's ones. These high Gini coefficients translate the frustration of the disadvantaged in all three countries with no exception.

\section{Competitiveness, Innovation, and the Business Environment}

The macroeconomic data indicate that overall, among the three countries, Egypt has struggled the most in the immediate aftermath of the Arab Spring, before recovering gradually in the recent years, Morocco has benefited from a more stable environment to gradually improve economically, while Tunisia has seen its economic dashboard deteriorating over the years and the situation does not seem to recover. The following sections will focus on the business environment by examining the progress of competitiveness indicators and their prerequisites.

\subsection{The Institutions}

The WEF Executive Opinion Surveys provide the factors considered as the most problematic for doing business in the included economies. Table 1 recapitulates the top three most problematic factors for the period 2009/102017/18 for the three economies under review. A surprising observation for Tunisia is that seven years after the revolution, corruption moved gradually from a low ranked barrier to business to the second most problematic factor for doing business in 2017/18. "Inefficient government bureaucracy" and "Policy instability" represent the two other obstacles to business in the top-three list. In Morocco, "corruption" and "inefficient government bureaucracy" were also the top two business barriers in 2017/18. Together with "access to financing", they have consistently been among the top-three list in the recent years. As for Egypt, the country has shown the most changing profile with multiple factors entering and exiting the top-three list throughout the years. "Policy instability" and "government instability" represent overall the two factors that most affected businesses in Egypt in the last decade though, while "corruption" and "inflation" became most problematic in 2017/18. 
INSIGHTS INTO REGIONAL DEVELOPMENT

ISSN 2669-0195 (online) http://jssidoi.org/jesi/

2021 Volume 3 Number 2 (June)

http://doi.org/10.9770/IRD.2021.3.2(5)

Table 1. Top-Three Most Problematic Factors for Doing Business

\begin{tabular}{|c|c|c|c|c|c|c|c|}
\hline & $2009 / 10$ & $2011 / 12$ & $2013 / 14$ & $2014 / 15$ & $2015 / 16$ & $2016 / 17$ & $2017 / 18$ \\
\hline & & \multicolumn{6}{|c|}{ Tunisia } \\
\hline Inefficient government bureaucracy & $1(14.3 \%)$ & $1(12.2 \%)$ & $2(11.9 \%)$ & $1(12.7 \%)$ & $1(16.4 \%)$ & $1(18.1 \%)$ & $1(18.1 \%)$ \\
\hline Corruption & $11(3.7 \%)$ & $7(7.1 \%)$ & $10(4.4 \%)$ & $6(6.7 \%)$ & $4(8.0 \%)$ & $3(11.7 \%)$ & $2(11.6 \%)$ \\
\hline Policy instability & $12(0.6 \%)$ & $4(10.8 \%)$ & $1(16.5 \%)$ & $3(11.8 \%)$ & $3(10.7 \%)$ & $2(13.8 \%)$ & $3(10.0 \%)$ \\
\hline Restrictive labor regulations & $3(11.5 \%)$ & $5(10.4 \%)$ & $6(7.2 \%)$ & $4(8.3 \%)$ & $10(4.9 \%)$ & $4(7.4 \%)$ & $4(8.1 \%)$ \\
\hline Government instability & $13(0.5 \%)$ & $3(11.0 \%)$ & $5(7.7 \%)$ & $8(5.4 \%)$ & $13(3.2 \%)$ & $12(4.3 \%)$ & $5(7.5 \%)$ \\
\hline \multirow[t]{2}{*}{ Access to financing } & $2(14.1 \%)$ & $2(11.9 \%)$ & $3(9.3 \%)$ & $2(12.3 \%)$ & $2(11.8 \%)$ & $5(6.4 \%)$ & $6(6.6 \%)$ \\
\hline & & \multicolumn{6}{|c|}{ Egypt } \\
\hline Inefficient government bureaucracy & $1(12.3 \%)$ & $4(9.1 \%)$ & $14(1.9 \%)$ & $14(2.7 \%)$ & $2(10.5 \%)$ & $14(2.7 \%)$ & $4(9.0 \%)$ \\
\hline Corruption & $5(9.5 \%)$ & $6(7.3 \%)$ & $5(7.5 \%)$ & $5(7.7 \%)$ & $12(4.1 \%)$ & $5(7.7 \%)$ & $3(9.8 \%)$ \\
\hline Policy instability & $15(0.7 \%)$ & $1(13.6 \%)$ & $1(22.9 \%)$ & $1(21.0 \%)$ & $1(11.8 \%)$ & $1(21.0 \%)$ & $1(15.2 \%)$ \\
\hline Government instability & $14(1.0 \%)$ & $8(6.4 \%)$ & $2(14.7 \%)$ & $2(12.5 \%)$ & $8(6.1 \%)$ & $2(12.5 \%)$ & $11(3.5 \%)$ \\
\hline Access to financing & $7(7.6 \%)$ & $3(10.6 \%)$ & $4(7.8 \%)$ & $3(10.2 \%)$ & $5(9.2 \%)$ & $3(10.2 \%)$ & $6(7.9 \%)$ \\
\hline Tax regulations & $2(12.0 \%)$ & $13(3.0 \%)$ & $12(4.2 \%)$ & $13(3.1 \%)$ & $13(3.9 \%)$ & $13(3.1 \%)$ & $13(3.0 \%)$ \\
\hline Poor work ethic in national labor force & $6(7.8 \%)$ & $7(7.1 \%)$ & $8(5.4 \%)$ & $8(5.4 \%)$ & $3(10.4 \%)$ & $7(5.4 \%)$ & $9(5.0 \%)$ \\
\hline Inadequately educated workforce & $3(10.4 \%)$ & $2(13.4 \%)$ & $6(6.4 \%)$ & $7(5.4 \%)$ & $4(10.1 \%)$ & $8(5.4 \%)$ & $5(7.9 \%)$ \\
\hline Inflation & $4(9.9 \%)$ & $10(4.6 \%)$ & $11(3.7 \%)$ & $12(3.2 \%)$ & $9(5.0 \%)$ & $12(3.2 \%)$ & $2(14.2 \%)$ \\
\hline \multirow[t]{2}{*}{ Crime and theft } & $11(4.5 \%)$ & $12(3.6 \%)$ & $3(9.3 \%)$ & $9(4.3 \%)$ & $10(4.5 \%)$ & $9(4.3 \%)$ & $16(0.7 \%)$ \\
\hline & & \multicolumn{6}{|c|}{ Morocco } \\
\hline Inefficient government bureaucracy & $5(8.8 \%)$ & $4(10.0 \%)$ & $1(19.1 \%)$ & $2(13.9 \%)$ & $2(15.6 \%)$ & $3(12.7 \%)$ & $2(13.8 \%)$ \\
\hline Corruption & $2(15.2 \%)$ & $2(17.7 \%)$ & $2(15.8 \%)$ & $6(10.0 \%)$ & $3(12.2 \%)$ & $6(10.5 \%)$ & $1(15.1 \%)$ \\
\hline Access to financing & $1(15.9 \%)$ & $1(18.6 \%)$ & $3(13.5 \%)$ & $1(16.3 \%)$ & $1(17.9 \%)$ & $1(15.4 \%)$ & $3(11.4 \%)$ \\
\hline Inadequate supply of infrastructure & $3(10.6 \%)$ & $3(11.6 \%)$ & $10(4.1 \%)$ & $4(10.2 \%)$ & $8(4.8 \%)$ & $8(5.7 \%)$ & $8(5.4 \%)$ \\
\hline Inadequately educated workforce & $6(8.3 \%)$ & $7(5.7 \%)$ & $6(7.9 \%)$ & $3(11.3 \%)$ & $4(11.2 \%)$ & $2(13.0 \%)$ & $5(10.3 \%)$ \\
\hline
\end{tabular}

Source: Data retrieved from the yearly Global Competitiveness Reports published by the World Economic Forum.

Percent of responses between brackets.

These country profiles suggest that the revolution, particularly in Tunisia, has amplified corruption, favoritism, and inefficiencies, the main reasons that set it off in the first place. The WEF institutions-related indicators confirm this observation (Appendix A). Although it is estimated that the total value of Ben Ali related clans confiscated assets in 2011 amounted to more than a quarter of Tunisia's GDP (Rijkers et al., 2017), which suggests outrageously corrupted industrial policies mainly captured by cronies, the WEF data suggest that the situation is worse off after the revolution. Despite establishing a Commission for Good Governance and AntiCorruption in the new 2014 constitution, corruption has eventually escalated (I Watch, 2015; Transparency International, 2016). Among the main reasons of these rising corruption levels is the decision made by the successive post-revolution governments to convert corrupted businessmen associated with the ancien régime into a political capital instead of prosecuting them or initiating a large scale reconciliation process. "After the revolution, a constant idea regularly came back: how to finance the political parties? The parties need businessmen and their money" declared AbdelFattah Mourou, one of the founders of Al-Nahda Islamic party and then Vice-President of the Tunisian Parliament, in an interview in 2014 (Kchouk, 2017). This granted entrepreneurs and the business elite, some of them were closely connected to Ben Ali's cronies, a safe and powerful come back as this gave them higher influence on the economic, but also the political decisions to further consolidate their resources and find new opportunities (Oubenal and Ben Hamouda, 2018).

The impact corruption had on the economy was augmented by the instable political scene and the highly volatile economic environment, especially in the aftermath of the assassination of Chokri Belaid in February 2013 and Mohamed Brahmi in July 2013, two important figures of the opposition to the Islamic-led government dominated by Al-Nahda (Matta et al., 2019). Moreover, "there were policy uncertainties associated with the political deadlock between secular and Islamic political leaders, some of whom wished to follow an Islamic economic 


\section{INSIGHTS INTO REGIONAL DEVELOPMENT}

ISSN 2669-0195 (online) http://jssidoi.org/jesi/

2021 Volume 3 Number 2 (June)

http://doi.org/10.9770/IRD.2021.3.2(5)

model similar to the one attempted by the Muslim Brotherhood in Egypt", explain Matta et al. (2019:248). AlNahda, whose public discourse articulates moderate positions on the role of religion in society, has been in reality courting groups with more extreme views such as Ansar-al-Sharia which between 2011 and 2013, and under the eyes of Al-Nahda government, occupied the public space, taking over more than 400 mosques where it selected jihadist imams who played a central role in galvanizing the base, recruiting Tunisian fighters for Syria, and reinforcing the jihadist base in the country (Serrano, 2019).

This political turmoil led to souring relationships and reduced trust of Tunisians in the ruling class and systems (Taylor and Miller, 2018). The WEF data confirm this reality. As shown in Appendix A, "Public trust in politicians", "irregular payments and bribe", "judicial independence", "favoritism in decisions of government officials", "burden of government regulation", "transparency of government policymaking", and "business cost of terrorism" are all indicators where Tunisia has collapsed over the last decade. An improvement has been recorded recently though in the transparency of the governmental budgeting process and the incidence of corruption, following the strict oversight exerted by the parliament over the government decisions and activities as a result of the nascent democratic system instituted by the 2014 constitution and gradually implemented thereafter.

Egypt started the decade in a worse situation compared to Tunisia. Contrary to Ben Ali who relied more on technocrats and kept the private capital out of the government and the parliament (Kchouk, 2017; Oubenal and Ben Hamouda, 2018), Mubarak gave entrepreneurs access to leading positions in the cabinet, and all ministers related to industrial development were owners of large enterprises (Altenburg, 2011). Moreover, firms connected to Mubarak crony, despite their lower financial performance, were "given" easier access to financing and larger market shares than their non-connected competitors (Chekir and Diwan, 2013; Darwisheh, 2012). After the Jan25 revolution, Egypt had a quasi U-shaped progress. Immediately after the revolution, the political and economic uncertainties reached their apex (Darwisheh, 2020). Until 2014, in addition to street violence and social turmoil, none of the governments that followed Mubarak ousting had presented clear policy directions for more equitable and sustainable economic transformation (Pfeifer, 2015). The situation gradually improved thereafter allowing Egypt to make major leaps forward, especially in reinforcing the independence of its judicial system and budget transparency. Corruption and terrorism remain serious threats to Egypt's transitional economy though.

Morocco started the decade in the worst position among the three economies for many of these indicators. In Morocco, similar to Egypt, entrepreneurs and businessmen had a substantial influence on policy making as ministers and, since 1997, as parliamentarians (Bennani-Chraïbi, 2008; El-Haddad, 2020). The structural institutional reforms gradually introduced after 2011 by King Mohamed VI and the Moroccan government helped the country close the gap and even overtake Tunisia and Egypt in areas such as public trust in politicians, incidence of corruption, burden of government regulations, transparency of government policymaking, and, expectedly, terrorism incidence. The reforms introduced have succeeded in changing the perceptions about the authoritarianism of the monarchy and the Makhzen, power structure surrounding the King, even though the 2011 constitution and the subsequent institutional reforms did not really change the monopolistic role the King holds as arbiter between the various forces, and the iron fist the Makhzen has on the country's economy and the various branches of power (Bergh and Rossi-Daria, 2015; Desrues, 2013).

Looking forward, the WEF data (Appendix A) reveal that Moroccans and Egyptians are more confident than Tunisians in the ability of their governments to ensure policy stability through a clear long term vision and responsiveness to change. The frequent reshufflings of governments and cabinets since 2011, coupled with the struggling economy, and lagging economic and social structural reforms seem to have cast a shadow over the Tunisians' trust in their politicians and their ability to ensure a brighter future for the country and its citizens. 
INSIGHTS INTO REGIONAL DEVELOPMENT

ISSN 2669-0195 (online) http://jssidoi.org/jesi/

2021 Volume 3 Number 2 (June)

http://doi.org/10.9770/IRD.2021.3.2(5)

\subsection{Competitiveness and Innovation}

Since the late 1980s, Tunisia, Egypt and Morocco have carved out important niches in the global apparel supply chain (Cammett, 2007). They have gradually become privileged suppliers of textile and clothing products to the European Union, counting on their proximity advantage and cheaper transport to win market shares over the strong Southeast Asian competition (World Bank, 2006). This global competitive advantage has been reinforced during the 1990s and 2000s by promoting industrial clusters as means to upgrade and boost industrial productivity and innovation.

The Programme de Mise à Niveau de l'Industrie (PMNI, Industrial Upgrading Programme) adopted in 1995 in Tunisia provided support for industrial companies to reinforce their competitive capacity and prepare their effective integration into global value chains (Ait Ali and Msadfa, 2016; ITCEQ, 2017). Although textile and clothing is still dominating with almost $70 \%$ of the manufacturing products (Ayadi and Mattoussi, 2014), the country has expanded its sectoral focus to other areas where Tunisia has been building a comparative advantage such as agrifood, mechanical and electric industries, as well as biotechnology, pharmaceuticals, healthcare and renewable energy (ECCP, 2017). Prior to the Jasmin revolution, nine industrial clusters have been established to encourage the development and internationalization of activities in these sectors. The PMNI continued after the revolution but its effectiveness has been remarkably limited for lack of strategic direction, making the preservation of the pre-revolution performance a challenging target (ITCEQ, 2017).

Cluster-based industrialization has also been a key pillar in Egypt's industrial development, especially with the adoption of the Industrial Development Strategy in 2005 (Ait Ali and Msadfa, 2016). This enabled an effective diversification of the economy into labor intensive sectors such as textile, furniture, leather, food processing, handicrafts, and medicinal and aromatic plants, but also into technology oriented sectors such as information and communication technologies (ICTs) with, notably, the establishment in 2001 of Smart Village, a state-of-the-art technology cluster and business park located in Western Cairo (Abdelaziz et al., 2018). Sustaining industrial clusters continued to play a central role after the Jan25 revolution and appears among the key pillars of Egypt's industry and trade development strategy 2016-2020 (Entrust, 2018; MTI, 2017). In addition to sustaining the traditional sectors, the strategy highlights clustering in value added sectors such as renewable energy, waste recycling, car components, and manufacturing machines and equipment, as key development axes.

In Morocco, the Emergency Plan 2005, the National Pact for Industrial Emergence 2009, the Industrial Acceleration Plan (IAP) 2014-2020, and the recently adopted IAP 2021-2025 represent the main frameworks guiding the public policies for industrial development and technological transformation (See Hahn and VidicanAuktor (2018) for a review of Morocco's economic models and industrial policies from 1950 to 2017). In addition to reinforcing Morocco's comparative advantage in textile, these successive plans have given birth to industrial clusters, mainly in agrifood, ICTs, microelectronics, renewable energies, aerospace, and the automotive sector. Most of these clusters are underperforming though, mainly due to a poorly structured research and innovation ecosystem, ill governance, and the lack of public-private partnerships (Amraoui et al., 2019). These shortcomings explain, at least partially, the modest progress Morocco had over the last decade with regards to its global competitiveness performance (Appendix A).

Morocco recorded a deterioration of the nature of its competitive advantage. Despite the heavy investments in its industrial development, Morocco's global competitive advantage is still based primarily on low-cost labor and low-value-added activities rather than on unique products and processes. This applies even to technology sectors such as automotive supplies (Hahn and Vidican-Auktor, 2017). Egypt and Tunisia have seen their performances completely collapsing here with Egypt's and Tunisia's global rankings plummeting from $35^{\text {th }}$ and $44^{\text {th }}$ in $2010 / 11$ to $95^{\text {th }}$ and $120^{\text {th }}$ in $2017 / 18$, respectively. The competitiveness of both countries was mainly affected by an overall significant deterioration in the intensity of local competition, the quantity and quality of local suppliers, 


\section{INSIGHTS INTO REGIONAL DEVELOPMENT}

ISSN 2669-0195 (online) http://jssidoi.org/jesi/

2021 Volume 3 Number 2 (June)

http://doi.org/10.9770/IRD.2021.3.2(5)

the breadth of their value chain, and the capacity of companies to innovate. Egypt has shown significant improvements in 2019 though, especially in the innovation capabilities of firms and the extent of market dominance, suggesting corporate activities that are spread among larger number of firms. Morocco has made some small steps forward on most of these fronts; steps that were insufficient to help the country make significant overall progress though.

The Global Innovation Index (GII) data (Appendix B) provide additional insight on the way the business environment has evolved in the three countries in the aftermath of the Arab Spring. Overall, Morocco has shown improvements compared to Tunisia and Egypt; although Tunisia still maintains the best relative position among the three countries in terms of overall innovation performance.

Tunisia has been significantly affected by the deteriorating state of its innovation clusters falling from a $56^{\text {th }} / 125$ global position in 2011 to $100^{\text {th }} / 129$ in 2019; an area where Egypt and Morocco succeeded to improve over the decade. Morocco's performance is largely attributable to the sustained development of its automotive cluster which has experienced a fresh momentum with the deployment of the country's second Renault plant in Tangier in 2012, and a Peugeot factory in Kenitra in 2019. By 2014, Morocco became the second-largest vehicle producer in Africa (Hahn and Vidican-Auktor, 2017), and by 2018 it surpassed South Africa as the leading automotive producer in the continent (Hakam, 2020; Kasraoui, 2018).

Moreover, from 2012 to 2017, Morocco succeeded in adding eight clusters to its network in various areas such as textile, seafood products, eco-constructions, and solar energy (Amraoui et al., 2019). As for Egypt, despite a setback in the years following the revolution, the country has succeeded as well in maintaining a relatively wellentrenched innovation clusters network, which was reinforced in 2017 by the establishment of Borg Al Arab Innovation Cluster specialized in Artificial Intelligence and the Internet of Things (Source: https://bit.ly/2UTkzlt) This placed Egypt in the best relative ranking (38 $/ 129)$ in the state of cluster development in 2019.

Tunisia still holds the best performance for the university/industry research collaboration, government effectiveness, and the ease of resolving insolvency, although the country was performing better in these areas in 2009/10 as compared to 2019. Morocco was more successful in maintaining easier procedures for entrepreneurs to start their businesses; an area where both Tunisia and Egypt have dramatically failed throughout the years. Overall, these data show that Tunisia, although struggling to sustain its overall innovation performance, is still ahead of Morocco and Egypt. However, this was only possible because of the deteriorating performance of Egypt and the modest improvements for Morocco over the last decade, rather than real advances for Tunisia.

\subsection{The Financial Market}

Financial support plays a critical role, especially in developing countries, to help businesses grow within a usually unfavorable institutional and business environment. Appendix A presents selected indicators reflecting the performance of financial markets in Tunisia, Egypt, and Morocco for the last decade. An alarming observation for Tunisia, which started the decade ahead of Egypt and Morocco along all parameters, is the dramatic gradual degradation of its performance, dragging the country down to the last relative position by the end of the decade. Egypt, which had a significant plunge along all indicators after the Jan 25 revolution, has quickly recovered and succeeded in gradually consolidating its financial systems starting 2016. In 2017/18, Egypt held the best relative position for the availability of financial services, and the ease of access to loans, and in 2019, it became best performer, comparatively, for the soundness of its banks, the financing of SMEs, and the venture capital availability. This performance is the result of sustained public efforts to boost economic activity and raise financial inclusion. In 2019, and in an effort to further promote SMEs financing, the backbone of the domestic economy, the Central Bank of Egypt obliged Egyptian banks to dedicate 20\% of their total loans portfolio to SMEs, which is expected to provide 350,000 SMEs with EGP 200bn (around \$12bn) within four years at an 


\section{INSIGHTS INTO REGIONAL DEVELOPMENT}

ISSN 2669-0195 (online) http://jssidoi.org/jesi/

2021 Volume 3 Number 2 (June)

http://doi.org/10.9770/IRD.2021.3.2(5)

interest rate of 5\% (Akinfieva, 2019). Despite this remarkable comeback, Egypt has not yet regained its 2010/11 performance for most of its financial market parameters.

Unexpectedly, Morocco degraded along all indicators, except the soundness of its banks. Morocco does not seem to have seized the opportunity of a decade of relative stability to strengthen its financial markets and provide better financial assistance to its businesses. To the opposite, almost all indicators have fallen over the last decade, most notably for the availability of venture capital and other financial services. The GII data (Appendix B) confirm this negative performance as the reported results place Morocco in the $94^{\text {th }} / 129$ position for the "ease of getting credit" in 2019,7 ranks below Tunisia $\left(87^{\text {th }}\right)$ and 40 positions below Egypt $\left(54^{\text {th }}\right)$.

\section{Infrastructure and Human Capital}

A review of the performance of the three countries cannot be complete without an examination of three key pillars to any economy: infrastructure, education, and labor market efficiency. The following sections provide details on the evolution of these economic pillars in Tunisia, Egypt and Morocco in the aftermath of the Arab Spring.

\subsection{Infrastructure Development}

Building the critical industrial infrastructure is an essential part of providing new opportunities for economic rebalance in post-Arab Spring North Africa (McCarthy, 2012). The years following the Arab Spring have seen infrastructure development following three different paths in the three countries, with Tunisia being the most significantly hit by the Arab Spring aftermath. Even though under Ben Ali's regime investments in most sectors remained under state control, and private investments and FDIs in infrastructure, among others, depended on the express authorization of the public authorities (Altenburg, 2011; Rijkers et al., 2017), Tunisia started the decade with the best quality of overall infrastructure, ahead of both Egypt and Morocco (Appendix C). Over the years, Tunisia has gradually slipped to the last relative position, ending the decade in the $85^{\text {th }} / 141$ rank, behind Egypt $\left(52^{\text {nd }}\right)$ and Morocco $\left(53^{\text {rd }}\right)$.

The relatively limited investments in the utility and transport related infrastructure since the revolution did not help Tunisia sustain its long standing comparative infrastructural advantage. To the opposite, Tunisia has seen its advantage reversed in all infrastructure related aspects with no exception. Egypt has made tremendous improvements, especially in enhancing the quality of its roads and the quality of electricity supply to end 2019 in the best relative position in those areas. The leadership shifted to Morocco for all remaining infrastructural aspects, although the efforts put forth in some areas such as the availability of latest technologies to firms, and firm-level technology absorption remain modest.

The significant improvements in Morocco are the result of the priority given to modern infrastructure development over the last decade, which placed the country as one of the best infrastructure hubs in the African continent (Ballard, 2020). Only for the period 2010-2015, the Moroccan government invested more than $\$ 15 \mathrm{bn}$ in upgrading and expanding its basic infrastructure (MCCG, 2019), which boosted Morocco's assets, especially for the quality of roads, port infrastructure and seaport services, and the quality of air transport infrastructure and services. Morocco's railroad infrastructure has also been bolstered with the inauguration in 2018 of the first high speed rail line in Africa connecting the northern port of Tangier with Rabat (the capital) and Casablanca (the main commercial hub); an investment of \$2.5bn (Berrada, 2018).

Egypt has seen a quasi U-shaped progress for most of its infrastructural indicators. The country has seen a dramatic slump of its infrastructure at all levels in the years following the Jan 25 revolution. In the period 20132016, Egypt's global positioning was beyond 100 for multiple years in the quality of roads, the quality of electricity supply, the availability of latest technologies, and the firm-level technology absorption. However, 


\section{INSIGHTS INTO REGIONAL DEVELOPMENT}

ISSN 2669-0195 (online) http://jssidoi.org/jesi/

2021 Volume 3 Number 2 (June)

http://doi.org/10.9770/IRD.2021.3.2(5)

improvements started to show up afterwards, especially in the quality of roads, the quality of railroad infrastructure and services, the quality of air transport infrastructure and services, and the quality of electricity supply. This is the result of the large scale infrastructure projects initiated by the government in the recent years such as the \$8.2bn expansion of the Suez Canal and its economic zone (BBC, 2015), and the 2018 construction boom leading Egypt to surpass Saudi Arabia as the second largest single projects market in the region with more than $\$ 33 \mathrm{bn}$ of contract awards and $\$ 300 \mathrm{bn}$ of projects in the pipeline (Egypt Today, 2019). In 2018, Egypt also secured 62 electricity and 40 drinking water projects, 100 high and medium technology and 186 traditional greenhouses for agriculture and farming, in addition to mega projects initiated to build or ensure maintenance for roads, highways, bridges, tunnels, railway lines, railcars, and railway systems (El Tawil, 2019).

In sum, from a pure infrastructure perspective, Morocco and Egypt have clearly overtaken Tunisia which has seen most of its infrastructure-related rankings dropping by more than 50 positions by the end of the decade.

\subsection{The Educational System}

Education is another fundamental pillar to any economy. It determines the quality of a country's human capital and its readiness to serve the country's needs. Historically, the Tunisian educational system has been one of the best in the Arab region following the strategic importance and the heavy investments made in this area since the independence of the country in 1956. Education, healthcare, and women emancipation are areas that Habib Bourguiba, founding President of the Republic, has given a central place in Tunisia's development strategy (Baccouche, 2016). These efforts continued under Ben Ali regime. From 1990 to 2010, the Tunisian government devoted an average of $6.3 \%$ of GDP to education (7.2\% in 2010), and in 2010, $6.2 \%$ of the adult population held a university degree, compared to a world average of 3.9\% (AfDB, 2012). Even though Ben Ali's policies have received criticisms with regards to education and healthcare particularly, he left power with Tunisia being in advanced global positions with regards to all education parameters and outcomes as shown in Appendix C.

In $2010 / 11$, Tunisia was $8^{\text {th }} / 139$ in the quality of math and science education, $20^{\text {th }} / 139$ in the overall quality of the education system, and $22^{\text {nd }} / 139$ in both the quality of primary education and the quality of management schools. Tunisia had also the best relative position for the enrollment rates in primary, secondary, and tertiary education. Tunisia had the best quality of scientific research institutions with a global ranking of $38^{\text {th }} / 139$, compared to $93^{\text {rd }}$ and $110^{\text {th }}$ for Morocco and Egypt, respectively. A decade later, Tunisia rankings have all collapsed, although the country is still ahead of Morocco and Egypt along all indicators, except the tertiary education enrolment rate and the prominence of research institutions, where Egypt became best in class. The collapse of the Tunisian educational system is alarming. Between 2010 and 2017, the country lost more than 80 positions in its global ranking for the overall quality of the educational system to crash to the $103^{\text {rd }} / 137$ rank. In 2019 , Tunisia was positioned $108^{\text {th }} / 141$ for the skillset of graduates and $99^{\text {th }}$ for the implementation of critical thinking in teaching.

Egypt has always suffered a lamentable educational system. The situation worsened after the Arab Spring, especially from 2013 to 2016 where the country was placed at the latest ranks globally. Although the situation has slightly improved later, the country is still among the worst globally in this area with a global ranking of $130^{\text {th }} / 137$ for its overall educational system in 2017/18, and 133\% 141 for the skillset of graduates in 2019.

The situation is only slightly better in Morocco compared to Egypt. Education is still an area where Morocco is deeply suffering as a result of decades of marginalization of the rural population, especially under the reign of King Hassan II (1961-1999). Contrary to Bourguiba, Hassan II made the forestalling of the emancipation of rural areas, which at the time represented $60 \%$ to $70 \%$ of the Moroccan population, one of the main arms of his strategy to control this large segment of the population and keep it depoliticized and disconnected from the urban centers (Bergh and Rossi-Doria, 2015). The illiteracy rates, which certainly have decreased over time from 65\% in 1982 to $43 \%$ in 2004, remain higher among the rural population where the illiteracy rate was of $60.5 \%$ in 2004 


\section{INSIGHTS INTO REGIONAL DEVELOPMENT}

ISSN 2669-0195 (online) http://jssidoi.org/jesi/

2021 Volume 3 Number 2 (June)

http://doi.org/10.9770/IRD.2021.3.2(5)

compared to $29.4 \%$ in the urban areas (Source: https://bit.ly/3ajTM8c). The Moroccan educational system further collapsed after the Arab Spring from 105 ${ }^{\text {th }} / 139$ in 2010/11 to $120^{\text {th }} / 137$ in 2017/18. Despite some improvements in the enrolment rates, Morocco posted huge degradation when it comes to education quality.

\subsection{Labor Market Efficiency}

Labor market efficiency is another important aspect that underlies development in any economy. It reflects the level of suitability between jobs and workers' skills and the level of incentives for both employers and employees to behave in ways that promote human capital productivity (Schwab and Sala-i-Martín, 2015). Here again, Tunisia started the decade in leading positions compared to Egypt and Morocco, and has gradually lost its advantage throughout the years (Appendix C). In 2010/11, Tunisia was ranked 40 th $/ 139$, and $52^{\text {nd }} / 139$ globally for the "reliance on professional management", and the "hiring and firing practices", to see its rankings deteriorate to $104^{\text {th }} / 141$ and $126^{\text {th }} / 141$ in 2019 , respectively. Tunisia lost its comparative advantage to Morocco $\left(58^{\text {th }}\right)$ for the former and to Egypt $\left(63^{\text {rd }}\right)$ for the latter.

The impact the Arab Spring had on Tunisia was also dramatic for the country's capacity to retain its "brains". The political and economic unrest and the lack of options and prospects resulted in a decade of massive waves of highly skilled professionals fleeing the country. It is estimated that the number of engineers who left the country amounted 10,000 in the period 2017-2019, while the number of medical doctors fleeing to France, Germany and the Gulf countries each year has doubled (Blaise et al., 2019). From 2011 to 2017, Tunisia's global position in the country's capacity to retain its talents plummeted from $42^{\text {nd }} / 139$ to $111^{\text {th }} / 137$, and in 2019 , Tunisia was $88^{\text {th }} / 141$ for the ease of finding skilled employees.

The comparison between the three economies shows that Egypt had the best overall accomplishments as it succeeded in improving considerably along most aspects related to its labor market. Despite starting the decade with a particularly unrewarding labor market for the relatively skilled (Campante and Chor, 2012), and a significant setback in the years following the revolution, Egypt was able to recover gradually starting 2014 for the country's capacity to retain talents, the availability of skilled employees, and the hiring and firing practices, areas in which Tunisia and Morocco had both declined. Egypt has also overtaken Tunisia for the "reliance on professional management" and finished 2019 thirteen positions ahead of Tunisia, but behind Morocco which from a mediocre performance in 2010/11 (105 $\left.{ }^{\text {th }} / 139\right)$, ended the decade in the best relative position $\left(58^{\text {th }} / 141\right)$. Morocco lost its comparative advantage to Egypt in "pay and productivity" though, which, despite a significant drop in the wake of the revolution, realized a remarkable rebound in 2018/19 to finish the decade in a leading $58^{\text {th }} / 141$ position, ahead of Morocco $\left(85^{\text {th }}\right)$ and Tunisia $\left(127^{\text {th }}\right)$.

\section{Political and Social Stability: A Thorny Challenge}

The above analysis shows that Tunisia started the decade as a role model in the Arab region in all aspects relating to its development pattern. This overall success was hiding growing deficiencies though; deficiencies that were at the basis of the Jasmin revolution. The favorable aggregate socio-economic indicators were actually hiding huge inequalities between the urban cities and the hinterland. Poverty rates, which certainly had improved overall during the 1990s and 2000s, were not reflecting the regional disparities within the country. In 2010, the announced official poverty rate in Tunisia was $2.55 \%$, albeit in reality poverty was affecting up to $30 \%$ of the population in inland areas (AfDB, 2012). The overall unemployment rate was an inaccurate representation of the rising unemployment among youth and university degree holders (Rougier, 2016). The authoritarian Police State regime implemented and carefully taken care of by Ben Ali intensified repressions of civil and political rights, and ensured repetitive extensions of Ben Ali's presidency through rigged elections. 


\section{INSIGHTS INTO REGIONAL DEVELOPMENT}

ISSN 2669-0195 (online) http://jssidoi.org/jesi/

2021 Volume 3 Number 2 (June)

http://doi.org/10.9770/IRD.2021.3.2(5)

The Jasmin revolution came as a peaceful revolt against this economic, social, and political injustice. It came to bring hope for a better future, hope for democracy, hope for respect of human rights, and hope for inclusive economic development. Today, Tunisia can boast of its democratic transition placing the country as most democratic Arab country (The EIU, 2020). Since the revolution, Tunisia has seen multiple peaceful democratic transitions of power between successive governments and Presidents. Unfortunately for Tunisians, this democratic rise-up did not translate into better living standards despite the huge potential the country had at the outset.

The reasons for this dilemma are multiple. First, the Tunisian democracy is still at its infancy stage. The EIU 2020 report classifies Tunisia as a "flawed" democracy. This group, includes countries where significant weaknesses persist despite the existence of free and fair elections. Although Tunisia scored among the best globally for its electoral process and pluralism, the country scores for civil liberties, political culture, and functioning of the government remain relatively low. These scores are due to a great extent to the rising interlock between politics and economics in the wake of the revolution, which in its turn led to rising levels of corruption, favoritism, and mediocre performance.

As explained earlier, contrary to Mubarak in Egypt and Mohamed VI in Morocco, Ben Ali had succeeded in keeping the private capital out of the government and the parliament. In pre-Arab Spring Egypt and Morocco, entrepreneurs and businessmen were granted easy access to leading political positions. Political decision making was therefore fundamentally influenced by the personal interests of the business elite in power. To the opposite, Ben Ali has always relied on qualified technocrats as ministers, and used his close allies to leverage his pressure on the business community to financially support his political and economic ambitions. An example is the placement of Hedi Jilani, a major player in Ben Ali's crony and closely connected to him through family ties, at the top of the UTICA, one of the largest and most important employers' organizations in the country. Jilani led the UTICA for 22 years during which he acted as Ben Ali's arm to keep an iron grip on economic activities and ensure their full support and generous contribution to the country's economic and social development strategies. Relying on qualified technocrat ministers was determinant in helping the country achieve greater overall economic success compared to neighboring countries, despite the economic and social disparities explained earlier, which, as it happened, were common to all countries in the region (Belhaj Hassine, 2015; Malik and Awadallah, 2013; Rougier, 2016).

The situation has fundamentally changed after the revolution. From a handful of active political parties under Ben Ali's regime, the Tunisian political scene has seen the number of parties exploding to reach 115 by the first elections held in 2011. By 2019 this number peaked to 219, although only a fraction had real political influence, including Al-Nahda, the dominant Islamic party, and a handful of other secular parties. These new players were in dire need of funding to gain popular recognition and attract supporters, and the only internal source of funding available was the business community. This has offered a number of Ben Ali's cronies a permissive transition, some of them have even seen their confiscated assets returned and political power augmented (Kchouk, 2017). The economic capital, which was barely involved in policy decision making under the ancien régime, became strongly influential politically through the formal and informal involvement in the parties, which skewed governmental decisions and prompted higher levels of corruption and nepotism.

The fragmented political arena resulted in fragmented parliaments requiring unnatural alliances between $\mathrm{Al}$ Nahda and secular parties to govern. Unlike the pre-revolution governments where technocrat ministers were appointed based on their expertise, most post-revolution governments were molded based on political quotas. Many ministers were sworn into office with no qualifications for the post. This lack of vision and competencies in leading political positions dramatically affected the performance of the successive governments. For instance, since the independence of the country in 1956, Tunisia governmental action has always been guided by five-year plans of economic and social development, known as plans de développement quinquennaux, prepared by the 


\section{INSIGHTS INTO REGIONAL DEVELOPMENT}

ISSN 2669-0195 (online) http://jssidoi.org/jesi/

2021 Volume 3 Number 2 (June)

http://doi.org/10.9770/IRD.2021.3.2(5)

finest economists and experts in the country. This planning process was suspended after the revolution and the planning aspect in the governmental action became limited to short term budgets preparation and execution. Longer term planning resumed later with the plan de développement quinquennal 2016-2020, but this plan sounded more like a wish list to attract FDIs rather than a realistic development plan taking into consideration the many challenges the country was facing.

Moreover, the intricate semi-presidential system instituted by the 2014 constitution has contributed to ongoing political stalemates. The endless worker strikes, road blockades, and calls for governments resignations added strains on the already tensed political and social context, and had all disruptive impacts on the economy. The multiple terrorist attacks and political assassinations came to add fuel to the general discontent, especially with mounting popular accusations against the Islamic party Al-Nahda, the only party that has been represented in all post-revolution governments, of complicity with terror by protecting terrorists and facilitating their movements.

Morocco has been spared this scenario as the reforms initiated following the F20M protests targeted incremental improvements within the continuity of the State and its pre-Arab Spring institutions. This ensured a relatively stable political and social context, which made it easier for the government to implement economic and social reforms that ensured incremental developments.

In Egypt, the Tunisian scenario has been observed to a greater extent in the few years following the Jan 25 revolution. Muslim Brothers (MB) and Salafists attracted more than 70\% of the votes in the 2011/12 parliamentary election (Elsayyad and Hanafy, 2014). Islamists' control over the political scene culminated in the election, in June 2012, of the MB candidate Mohamed Morsi as President of Egypt with 51.7\% of the vote. Morsi's term as President was marked by extreme controversies. Popular discontent emerged against his policies blindly following the MB Guidance Office's directives and serving the movement's interests and agenda. Public outrage reached its peak in November 2012 with the sudden issuing of a presidential decree proclaiming all constitutional declarations, laws, and decrees issued by the President since he took office and until a new constitution is approved, final, binding, and cannot be appealed by any way or to any entity, nor shall they be suspended or canceled and all lawsuits related to them and brought before any judicial body against them are annulled (Al-Ahram, 2012). This move led to massive protests all over the country and violent clashes were reported between protesters and the police. "Morsi today usurped all state powers \& appointed himself Egypt's new pharaoh. A major blow to the revolution that cld have dire consequences" Twitted Mohamed ElBaradei following the announcement (Birnbaum, 2012). Morsi's declaration was also condemned by Egypt's highest body of judges, and human rights groups such as Amnesty International, Human Rights Watch, and Freedom House.

Morsi's controversial decisions continued after this crisis, which ultimately pushed millions of people to rally in Tahrir square and across Egypt on June 30, 2013, calling for his resignation. The scene recalled Jan25 revolution days and obliged the Supreme Council of the Armed Forces to intervene by giving a 48-hour ultimatum to political parties to heed "the will of the people", and warned to intervene if the situation was not resolved. One day later, Morsi rejected publicly the Army statement, sparking further anger among protesters (Bowen, 2013). The conflict became a stalemate, which pushed the Army to intervene by ousting Morsi from office and appointing Adly Mansour, the head of the Constitutional Court, as Interim President. Mansour served as Interim President until June 8, 2014, the day AbdelFattah Al-Sissi was sworn into office as President of Egypt after winning the May 2014 Presidential elections.

Al-Sissi declared a fierce war against terrorism. The violent reactions of the MB believed to have carried out suicide bombings and political assassinations to revenge Morsi ousting have led to declaring them a terrorist organization. Contradicting reactions have been put forth to describe Morsi ousting. While MB's supporters call it an illegitimate coup, others consider it as an inevitable course correction of Jan 25 revolution, which saved Egypt from the MB's grip. One thing is for sure though, what happened enabled a regain in socio-political stability, 


\section{INSIGHTS INTO REGIONAL DEVELOPMENT}

ISSN 2669-0195 (online) http://jssidoi.org/jesi/

2021 Volume 3 Number 2 (June)

http://doi.org/10.9770/IRD.2021.3.2(5)

which in its turn contributed to a great extent into the economic recovery observed in the recent years as explained earlier in this paper.

\section{Conclusions}

The objective of this paper was to analyze the economic performance and institutional changes that have taken place in Egypt, Tunisia, and Morocco following the Arab Spring, and understand the interconnect between the socio-political context on the one side, and economic performance and growth on the other side, in a period marked by severe turbulences, especially in Tunisia and Egypt. Our analysis shows that the script for the three countries is fundamentally different. Economically, Morocco has benefitted from a relatively stable political context to sustain a positive economic growth. Egypt, has been severely hit economically in the wake of the Jan 25 revolution but has gradually recovered in the recent years. As for Tunisia, the decade-long economic trend had an overall negative slope and the situation does not seem to be recovering. A similar trend is observed overall for most institutional, competitiveness, and business environment indicators with Morocco showing positive incremental improvements at different degrees, versus a U-shaped progress for Egypt, and a deteriorating performance for Tunisia.

The parallel between political and social stability and economic performance in pre and post-Arab Spring eras, clearly reveals that the economic woes Egypt and Tunisia witnessed post 2011 were principally due to the generalized instability in both countries resulting of the growing political contentions. The Arab Spring came as a popular rebellion against autocratic regimes which, for decades, restricted political liberties, controlled economic resources, and ignored social problems. Our analysis shows that from a pure economic perspective, the Tunisian scenario yielded the least returns, while from a political point of view, Tunisia has undergone the most remarkable democratic transition. The Egyptian scenario confirms this parallel. The democracy index surveys over the last decade, show that Egypt scored its best democracy performance in 2012; although the score achieved placed the country as barely hybrid regime, far below even the "flawed" democracy status. Year 2012, was also the year the socio-political turmoil in the country reached its peak and led to a serious economic downturn. This raises a fundamental question: is democracy and obstacle to socio-political stability in the region, which in its turn is a prerequisite to economic performance?

The decade long experience in Tunisia, and Egypt's struggling in the wake of Jan25 revolution seem to bring an affirmative answer to this question. However, this answer needs to be nuanced as Tunisia and Egypt democracies are far from being perfect ones. The Tunisian democracy is still "flawed". The weak political culture and the tensed political polarization between the religious party, Al-Nahda, and opposing secular parties are significantly affecting the polls. In most municipal, parliamentary, and presidential elections held after the Jasmin revolution, almost no party provided clear and coherent economic and social programmes, and the voting process was to a great extent influenced by the ideological orientations of voters and the financial subsidies provided prior to each ballot by the candidates to needy electors. The political competition became one based on ideologies and financial power of parties rather than concrete developmental visions, strategies and plans.

The political strife shifted after each election to the institutions of the State, the parliament in particular. Secular deputies continue to accuse $A l-N a h d a$ of complicity with terror mainly because of its historical connections with the MB movement in Egypt and the controversial decisions Al-Nahda made in support of Morsi regime in Egypt and terrorist members in Tunisia. On the other side, Al-Nahda is accusing secular deputies of obstructing the course of the revolution by disrupting parliament's work. Amidst these political tensions, the economic and social discourses have rarely risen up to higher levels in the priorities and discussions between the parties involved. In Egypt, the situation was made worse by the higher levels of poverty and illiteracy, which clearly undermined the democratic process in the country. The intense polarization between the Islamic and secular parties ultimately culminated into the 2012 political deadlock. 


\section{INSIGHTS INTO REGIONAL DEVELOPMENT}

ISSN 2669-0195 (online) http://jssidoi.org/jesi/

2021 Volume 3 Number 2 (June)

http://doi.org/10.9770/IRD.2021.3.2(5)

In the light of these results, it is clear that the relationship between political regimes and economic development needs further investigation in the specific context of Arab countries. While pure authoritarian regimes were clearly a failure, which led to the Arab Spring massive protests, "Western" democracy has also shown its limits when applied within the Arab region context, as it led to neither political stability, nor economic growth. It is worth noting here that studies on the relation between democracy and economic development suggest that democratic transitions often occur randomly, but once there, only countries achieving economic growth remain democratic (Epstein et al., 2006; Przeworski et al., 2000). Future research are therefore needed within this perspective.

At the time these words are being written, Egypt and Morocco seem to benefit from a relatively more stable environment to continue their economic and social progress. In Tunisia, political contentions are still ongoing and reached new heights in the Tunisian Parliament with an extreme polarization between Al-Nahda and its allies from the one side, and the opposition led by the Free Destourian Party on the other side. The newly formed government is cautiously navigating through the tensions caused by the fragile governmental alliance between $A l$ Nahda and some of its historical opponents, the stiff relationship with the Parliament, and the standoff between the Parliament and the President of the Republic. The COVID-19 global pandemic came to put more strain on the already battered economy. Regaining political stability remains a condition sine qua non for economic recovery and inclusive development; the key claims of the Jasmin revolution. Unless this happens, the whole Tunisian experience remains at stake and its democratic transition threatened.

\section{References}

Abdelaziz F., El-Enbaby H., Zhang X., Breisinger C. 2018. Clusters as drivers of local industrial development in Egypt. Which are the promising sectors and locations? Working Paper 10, Middle East and North Africa Regional Program Working Paper series, June 2018, Retrieved from: https://bit.ly/2Xmoyss

Acemoglu D., Hassan T. A., Tahoun A. 2018. The Power of the Street: Evidence from Egypt's Arab Spring, The Review of Financial Studies, 31(1), 1-42.

African Development Bank (AfDB). 2012. African Economic Outlook: Tunisia 2012. Retrieved from: https://bit.ly/2Rj7HCZ

Ait Ali A., Msadfa Y. 2016. Industrial policy, Structural Change and Global Value Chains Participation: Case study of Morocco, Tunisia and Egypt, Policy Paper16/04, OCP Policy Center. Retrieved from: https://bit.ly/3c4rf63

Akinfieva Y. 2019, January 16. SME Financing in Egypt, Mondaq, Retrieved from: https://bit.ly/2JMcLLZ

Al-Ahram. 2012, November 22. Al-Ahram Gate publishes the full text of the decisions: Morsi fortifies his decisions with a constitutional declaration and prevents the dissolution of the constituent assembly and the Shura council (Arabic text), Retrieved from: https://bit.ly/2Vjvmp5

Altenburg T. 2011. Industrial policy in developing countries: Overview and lessons from seven country cases. Discussion paper 4/2011. German Development Institute, Bonn.

Amraoui B., Ouhajjou A., Monni S., El Amrani El Idrissi N., Tvaronavičienė M. 2019. Performance of clusters in Morocco in the shifting economic and industrial reforms, Insights into Regional Development, 1(3), 227-243.

Ayadi M., Mattoussi W. 2014. Disentangling the pattern of geographic concentration in Tunisian manufacturing industries, WIDER Working Paper 2014/072, World Institute for Development Economics Research, United Nations University, Helsinki, Finland.

Baccouche N. 2016. Economic and social rights and the Tunisian Constitution. New York: United Nations Development Programme, Arab States.

Ballard B. 2020, January 31. Morocco's infrastructural investment gap is hitting rural areas hardest, World Finance, Retrieved from: https://bit.ly/2XP1Rxp

BBC. 2015, August 6. Egypt launches Suez Canal expansion, Retrieved from: https://bbc.in/3e0wWUh

Belhaj Hassine N. 2015. Economic Inequality in the Arab Region, World Development, 66, 532-556.

Bennani-Chraïbi M. 2008. "Hommes d'affaires" versus "profs de fac". La notabilisation parlementaire d'un parti de militants au Maroc. Revue Internationale de Politique Comparée, 15(2), 205-219.

Bergh S. I., Rossi-Doria D. 2015. Plus ça change? Observing the dynamics of Morocco's 'Arab Spring' in the high atlas. Mediterranean Politics, 20(2), 198-216.

Berrada E.M. 2018, July 24. Le Maroc paie son TGV au prix fort, Jeune Afrique, Retrieved from: https://bit.ly/2RJSvix

Birnbaum M. 2012, November 22. Egypt's President Morsi takes sweeping new powers, The Washington Post, Retrieved from: https://wapo.st/2VFowt1 


\section{INSIGHTS INTO REGIONAL DEVELOPMENT}

ISSN 2669-0195 (online) http://jssidoi.org/jesi/

2021 Volume 3 Number 2 (June)

http://doi.org/10.9770/IRD.2021.3.2(5)

Blaise L., Tlili H., Szakal V. 2019, January 18. Tunisia looks for ways to stem 'brain drain', France 24 Report, Retrieved from: https://bit.ly/2xqloJL

Bowen J. 2013, July 2. Egypt President Morsi warns of army ultimatum 'confusion', BBC News, Retrieved from: https://bbc.in/34NXoMB

Brockmeyer A., Khatrouch M., Raballand G. 2015. Public Sector Size and Performance Management: A Case-Study of Post-Revolution Tunisia, Policy Research Working Paper 7159, World Bank Group. Retrieved from: https://bit.ly/39YCNGv

Burger M., Ianchovichina E., Rijkers B. 2013. Risky Business: Political Instability and Greenfield Foreign Direct Investment in the Arab World. Policy Research Working Paper Series, WP 6716, The World Bank.

Cammett M. 2007. Business-Government Relations and Industrial Change: The Politics of Upgrading in Morocco and Tunisia, World Development, 35(11), 1889-1903.

Campante, F., Chor D. 2012. Why was the Arab World Poised for Revolution? Schooling, Economic Opportunities, and the Arab Spring, Journal of Economic Perspectives, 26(2), 167-188.

Chekir H., Diwan I. 2013. Distressed Whales on the Nile - Egypt Capitalists in the Wake of the 2010 Revolution, Working Paper 747, Working Papers Series, The Economic Research Forum.

Coşkun E.R. 2019. The role of emotions during the Arab Spring in Tunisia and Egypt in light of repertoires, Globalizations, 16(7), 11981214.

Costello M., Jenkins J.C., Aly H. 2015. Bread, Justice, or Opportunity? The Determinants of the Arab Awakening Protests, World Development, 67, 90-100.

Hakam A. 2020. L'industrie automobile au Maroc: Vers de nouveaux gisements de croissance, DEPF (Direction des Etudes et des Prévisions Financières). Retrieved from: https://bit.ly/2yF95Jy

Darwisheh, H. 2012. Egypt in the Era of Hosni Mubarak 1981-2011 by Amin, Galal, Book Review, The Developing Economies, 50(1), 7578

Darwisheh, H. 2020. The Political Economy of Reforms in Egypt: Issues and Policymaking since 1952 by Khalid Ikram, Book Review, The Developing Economies, 58(2), 186-189

Desrues T. 2013. Mobilizations in a hybrid regime: the 20th February movement and the Moroccan regime, Current Sociology, 61(4), 409423.

Egypt Today. 2019, June 13. 'The Big 5 Construct Egypt' grows as report reveals $\$ 300$ billion of planned projects, Retrieved from: https://bit.ly/2xcXtNv

El-Haddad A. 2020. Redefining the social contract in the wake of the Arab Spring: The experiences of Egypt, Morocco and Tunisia, World Development, 127, 1-22.

Elsayyad M., Hanafy S. 2014. Voting Islamist or voting secular? An empirical analysis of voting outcomes in Egypt's "Arab Spring", Public Choice, 160, 109-130.

El Tawil N. 2019, January 30. The Major Projects of 2018-19, Egypt Today, Retrieved from: https://bit.ly/3bRavz4

Entrust (Development and Management Consultants). 2018. Egypt's National Strategy for the Development of Organic Clusters: 20192030. Retrieved from: https://bit.ly/2VcTokB

Epstein, D. R., Bates, J., Goldstone, I., Kristensen, S., O’Halloran, S. 2006. Democratic Transitions, American Journal of Political Science, 50(3), 551-569.

European Cluster Collaboration Platform (ECCP). 2017. Tunisia, July 31. Retrieved from: https://bit.ly/3ebP2my

Ghanmi L. 2019, October 12. Tunisia's phosphates company at risk of collapse. The Arab Weekly, Retrieved from: https://bit.ly/2Xf6EHQ

Hahn T., Vidican-Auktor G. 2018. Industrial Policy in Morocco and its Potential Contribution to a New Social Contract. Discussion Paper 31/2018, German Development Institute (DIE), Bonn.

Hahn T., Vidican-Auktor G. 2017. The effectiveness of Morocco's industrial policy in promoting a national automotive industry. Discussion Paper 27/2017, German Development Institute (DIE), Bonn.

Institut Tunisien de la Compétitivité et des Études Quantitatives (ITCEQ). 2017. Programme de Mise à Niveau : Bilan, réalisations et perspectives. Retrieved from: https://bit.ly/3a4U0yc

I Watch. 2016. Etude sur le systeme national d'integrite Tunisie 2015, project conducted by I Watch Organization and Transparency

International and funded by the European Union. Retrieved from: https://bit.ly/2Xhy9Rl

Kasraoui S. 2018, October 1. WSJ: Morocco is Leading Africa's Automotive Industry, Morocco World News, Retrieved from: https://bit.ly/3e1M97A

Kchouk B. 2017. Les "anciennes" élites économiques et le changement de régime en Tunisie: de l'incertitude vers la consolidation politicoéconomique des positions, Politix, 2017/4(120), 157-178.

Kienle E. 2012. Egypt without Mubarak, Tunisia after Bin Ali: theory, history and the 'Arab Spring', Economy and Society, 41(4), 532557.

McCarthy D. A. 2012. Economic Rebalance: The Role of Infrastructure in the Success of the Arab Spring, National Council on U.S. Arab Relations, Infrastructure and Business Opportunities in North Africa Event, Washington, DC, Retrieved from: https://bit.ly/2RDjDQ1

Looney R. 2014. The Little Monarchies That Could. How Oman, Jordan, and Morocco Survived the Arab Spring. The Milken Institute Review, 2nd Quarter, 34-43.

Mabon S. 2013. Aiding Revolution? Wikileaks, communication and the 'Arab Spring' in Egypt. Third World Quarterly, 34(10), 18431857.

Malik A., Awadallah B. 2013. The Economics of the Arab Spring. World Development, 45, 296-313. 


\section{INSIGHTS INTO REGIONAL DEVELOPMENT}

ISSN 2669-0195 (online) http://jssidoi.org/jesi/

2021 Volume 3 Number 2 (June)

http://doi.org/10.9770/IRD.2021.3.2(5)

Matta S., Appleton S., Bleaney M. 2019. The Impact of the Arab Spring on the Tunisian Economy. The World Bank Economic Review, 33(1), 231-258.

Mekki N. 2018. The political crisis in Tunisia: Is it a consequence of the semipresidential arrangement? ConstitutionNet. Retrieved from: https://bit.ly/2x2Ys30

Ministry of Trade and Industry (MTI). 2017. Industry and Trade Development Strategy 2016 - 2020. Retrieved from: https://bit.ly/2Xp1hWG

Morocco Country Commercial Guide (MCCG). 2019. Morocco - Infrastructure. Select USA. Retrieved from: https://bit.ly/2K3LCnQ

Oubenal M., Ben Hamouda A. 2018. The political economy of business elites in Tunisia: Actors, strategies, and identities. Working paper No. 1273, Working Papers Series, Economic Research Forum.

Pearlman W. 2013. Emotions and the Microfoundations of the Arab Uprisings. Perspectives on Politics, 11(2), $387-409$.

Pfeifer K. 2015. The Tortuous Path to a New Economic Agenda in Egypt and Tunisia. Athens Journal of Mediterranean Studies, 1(1), 924.

Przeworski, A., Alvarez, M., Cheibub, J., Limongi, F. 2000. Democracy and Development: Political Institutions and Well-Being in the World, 1950-1990. Cambridge: Cambridge University Press.

Raballand G., Veuillot G., Habhab L., de Meneval P. 2015. Middle East and North Africa Governance Reforms of State-Owned Enterprises (SOEs) Lessons from four case studies (Egypt, Iraq, Morocco and Tunisia), Report No: ACS15142. Retrieved from: https://bit.ly/3e911Rz

Rijkers B., Freund, C., Nucifora A. 2017. All in the Family: State Capture in Tunisia. Journal of Development Economics, 124, 41-59.

Rougier E. 2016. "Fire in Cairo": Authoritarian-Redistributive Social Contracts, Structural Change, and the Arab Spring. World Development, 78, 148-171.

Schwab K., Sala-i-Martín X. 2015. The Global Competitiveness Report 2015-2016, World Economic Forum, Geneva.

Serrano F. 2019, April 23. Is Tunisia's Post-Arab Spring 'Success Story' Only Skin-Deep? World Politics Review, Retrieved from: https://bit.ly/34EG0tV

Taylor A., Miller E. 2018, January 14. What's next? Seven years after Tunisia's spring. Atlantic Council, Retrieved from: https://bit.ly/34C1OGg

The Economist Intelligence Unit (EIU). 2020. Democracy Index 2019: A year of democratic setbacks and popular protest, report published by The Economist Intelligence Unit, Retrieved from: https://bit.ly/369hq69

Transparency International. 2016. People and Corruption: Middle East and North Africa Survey 2016, report published May 3, 2016.

Turki S. Y., Verdeil E. 2015. Tunisie: la Constitution (du Printemps) Ouvre le Débat sur la Décentralisation, in Harb M., Atallah S. (Ed.) Local Governments and Public Goods: Assessing Decentralization in the Arab World. The Lebanese Center for Policy Studies, 11-45.

World Bank. 2006. Morocco, Tunisia, Egypt and Jordan after the end of the multi-fiber agreement. Washington, D.C., World Bank, Report No. 35376, MNA.

World Bank. 2014. The Unfinished Revolution: Bringing Opportunity, Good Jobs and Greater Wealth to all Tunisians, Development Policy Review, Washington DC: World Bank, published May 2014.

\section{Appendix}

\section{A. Selected Competitiveness Indicators}

\begin{tabular}{|c|c|c|c|c|c|c|c|}
\hline & Country & $2010 / 11^{*}$ & $2013 / 14$ & $2015 / 16$ & $2017 / 18$ & $2018^{* *}$ & 2019 \\
\hline Number of economies included & & 139 & 148 & 140 & 137 & 140 & 141 \\
\hline \multirow{3}{*}{$\begin{array}{l}\text { Global Competitiveness Score (rank } \\
\text { between brackets) }\end{array}$} & Tunisia & $4.65(32)$ & $4.06(83)$ & $3.93(92)$ & $3.93(95)$ & $55.6(87)$ & $56.4(87)$ \\
\hline & Egypt & $4.00(81)$ & $3.63(118)$ & $3.66(116)$ & $3.90(100)$ & $53.6(94)$ & $54.5(93)$ \\
\hline & Morocco & $4.08(75)$ & $4.11(77)$ & $4.17(72)$ & $4.24(71)$ & $58.5(75)$ & $60.0(75)$ \\
\hline \multicolumn{8}{|l|}{ INSTITUTIONS } \\
\hline \multirow{3}{*}{$\begin{array}{l}\text { Public trust in politicians ("future } \\
\text { orientation of government" reported for } \\
2018 \text { \& 2019) }\end{array}$} & Tunisia & $-(15)$ & $3.3(53)$ & $3.0(64)$ & $2.9(75)$ & $37.5(98)$ & $55.2(72)$ \\
\hline & Egypt & $-(40)$ & $2.8(82)$ & $2.8(83)$ & $3.0(67)$ & $47.8(57)$ & $60.0(43)$ \\
\hline & Morocco & $-(59)$ & $3.1(64)$ & $3.4(50)$ & $3.4(53)$ & $51.2(46)$ & $60.3(42)$ \\
\hline \multirow{3}{*}{$\begin{array}{l}\text { Irregular payments and bribe ("incidence } \\
\text { of corruption" reported for } 2018 \text { \& } \\
2019 \text { ) }\end{array}$} & Tunisia & $-(33)$ & $3.9(69)$ & $3.6(92)$ & $3.5(88)$ & $42.0(63)$ & $43.0(62)$ \\
\hline & Egypt & $-(64)$ & $3.4(101)$ & $4.1(60)$ & $4.2(57)$ & $32.0(99)$ & $35.0(91)$ \\
\hline & Morocco & $-(82)$ & $4.3(59)$ & $4.1(58)$ & $3.7(78)$ & $40.0(69)$ & $43.0(62)$ \\
\hline \multirow[t]{3}{*}{ Judicial independence } & Tunisia & $-(40)$ & $3.6(77)$ & $3.8(71)$ & $3.8(70)$ & $3.9(66)$ & $3.7(77)$ \\
\hline & Egypt & $-(63)$ & $3.5(82)$ & $4.5(45)$ & $5.1(31)$ & $5.2(29)$ & $4.9(34)$ \\
\hline & Morocco & $-(79)$ & $3.4(87)$ & $3.5(83)$ & $3.8(75)$ & $3.9(65)$ & $4.1(55)$ \\
\hline \multirow{3}{*}{$\begin{array}{l}\text { Favoritism in decisions of government } \\
\text { officials }\end{array}$} & Tunisia & $-(12)$ & $3.4(44)$ & $3.3(55)$ & $3.3(55)$ & - & - \\
\hline & Egypt & $-(95)$ & $3.0(80)$ & $4.1(25)$ & $3.5(48)$ & - & - \\
\hline & Morocco & $-(52)$ & $3.4(46)$ & $3.5(46)$ & $3.4(50)$ & - & - \\
\hline
\end{tabular}


INSIGHTS INTO REGIONAL DEVELOPMENT

ISSN 2669-0195 (online) http://jssidoi.org/jesi/ 2021 Volume 3 Number 2 (June) http://doi.org/10.9770/IRD.2021.3.2(5)

\begin{tabular}{|c|c|c|c|c|c|c|c|}
\hline \multirow[t]{3}{*}{ Burden of government regulation } & Tunisia & - (15) & $3.5(71)$ & $3.3(84)$ & $3.0(103)$ & $3.0(103)$ & $2.9(112)$ \\
\hline & Egypt & $-(79)$ & $3.2(96)$ & $3.5(60)$ & $3.2(87)$ & $3.2(87)$ & $3.4(75)$ \\
\hline & Morocco & $-(61)$ & $3.5(64)$ & $3.5(58)$ & $3.8(39)$ & $4.1(25)$ & $4.1(23)$ \\
\hline \multirow{3}{*}{$\begin{array}{l}\text { Transparency of government } \\
\text { policymaking ("budget transparency" } \\
\text { reported for } 2018 \& 2019 \text { ) }\end{array}$} & Tunisia & $-(20)$ & $4.0(82)$ & $3.7(100)$ & $3.9(79)$ & $46.2(90)$ & $39(66)$ \\
\hline & Egypt & $-(68)$ & $3.9(90)$ & $3.7(99)$ & $3.0(129)$ & $38.5(110)$ & $41.0(63)$ \\
\hline & Morocco & $-(76)$ & $4.2(66)$ & $4.4(43)$ & $4.4(49)$ & $50.0(77)$ & $45.0(56)$ \\
\hline \multirow{3}{*}{$\begin{array}{l}\text { Business costs of terrorism ("terrorism } \\
\text { incidence" reported for } 2018 \& 2019 \text { ) }{ }^{* * *}\end{array}$} & Tunisia & $-(28)$ & $3.8(137)$ & $3.4(128)$ & $3.2(128)$ & $97.7(105)$ & $97.9(106)$ \\
\hline & Egypt & $-(132)$ & $2.6(148)$ & $2.7(138)$ & $4.5(104)$ & $41.6(135)$ & $41.6(136)$ \\
\hline & Morocco & $-(84)$ & $5.3(81)$ & $5.8(39)$ & $5.3(56)$ & $100(28)$ & $100(29)$ \\
\hline \multicolumn{8}{|c|}{ BUSINESS COMPETITVENESS \& INNOVATION } \\
\hline \multirow[t]{3}{*}{ Nature of competitive advantage } & Tunisia & $-(44)$ & $3.5(64)$ & $2.8(119)$ & $2.6(120)$ & - & - \\
\hline & Egypt & $-(35)$ & $3.5(66)$ & $3.2(90)$ & $3.1(95)$ & - & - \\
\hline & Morocco & $-(73)$ & $3.2(94)$ & $2.9(109)$ & $3.2(87)$ & - & - \\
\hline \multirow{3}{*}{$\begin{array}{l}\text { Intensity of local competition ("extent of } \\
\text { market dominance" reported for } 2018 \text { \& } \\
2019 \text { ) *** }\end{array}$} & Tunisia & $-(34)$ & $4.9(80)$ & $4.7(90)$ & $5.0(79)$ & $3.6(79)$ & $3.6(87)$ \\
\hline & Egypt & $-(91)$ & $4.1(131)$ & $4.2(128)$ & $4.8(88)$ & $3.9(47)$ & $4.3(36)$ \\
\hline & Morocco & $-(69)$ & $5.1(60)$ & $5.0(73)$ & $5.2(64)$ & $3.7(67)$ & $3.8(69)$ \\
\hline \multirow{3}{*}{ Local supplier quantity } & Tunisia & $-(14)$ & $4.9(46)$ & $4.4(82)$ & $4.8(38)$ & - & - \\
\hline & Egypt & $-(36)$ & $4.6(85)$ & $4.5(68)$ & $4.3(85)$ & - & - \\
\hline & Morocco & $-(52)$ & $4.6(84)$ & $4.6(55)$ & $4.8(31)$ & - & - \\
\hline \multirow[t]{3}{*}{ Local supplier quality } & Tunisia & $-(45)$ & $4.2(84)$ & $3.9(97)$ & $4.1(83)$ & - & - \\
\hline & Egypt & $-(89)$ & $4.1(100)$ & $3.8(109)$ & $4.0(95)$ & - & - \\
\hline & Morocco & $-(78)$ & $4.4(71)$ & $4.1(83)$ & $4.3(68)$ & - & - \\
\hline \multirow[t]{3}{*}{ Value chain breadth } & Tunisia & $-(24)$ & $3.8(61)$ & $3.6(88)$ & $3.7(78)$ & - & - \\
\hline & Egypt & $-(67)$ & $3.6(79)$ & $3.7(73)$ & $3.9(56)$ & - & - \\
\hline & Morocco & $-(70)$ & $3.7(76)$ & $3.8(68)$ & $3.9(58)$ & - & - \\
\hline \multirow[t]{3}{*}{ Willingness to delegate authority } & Tunisia & $-(60)$ & $3.4(104)$ & $3.4(103)$ & $3.6(122)$ & $3.8(116)$ & $4.1(98)$ \\
\hline & Egypt & $-(57)$ & $4.1(40)$ & $4.2(34)$ & $3.7(118)$ & $3.9(102)$ & $4.1(88)$ \\
\hline & Morocco & $-(96)$ & $3.4(107)$ & $3.6(82)$ & $3.9(98)$ & $4.1(80)$ & $4.1(90)$ \\
\hline \multirow{3}{*}{$\begin{array}{l}\text { Capacity for innovation (“innovation } \\
\text { capability" reported for } 2018 \& 2019 \text { ) }{ }^{* *}\end{array}$} & Tunisia & $-(36)$ & $3.2(99)$ & $3.5(109)$ & $3.8(93)$ & $32.7(84)$ & $32.6(92)$ \\
\hline & Egypt & $-(109)$ & $3.1(111)$ & $3.1(133)$ & $3.4(123)$ & $37.7(64)$ & $39.6(61)$ \\
\hline & Morocco & $-(94)$ & $2.8(129)$ & $3.5(108)$ & $3.9(83)$ & $34.0(78)$ & $35.1(81)$ \\
\hline \multicolumn{8}{|l|}{ FINANCIAL MARKET } \\
\hline \multirow[t]{3}{*}{ Availability of financial services } & Tunisia & $-(42)$ & $3.9(100)$ & $3.7(121)$ & $3.7(106)$ & - & - \\
\hline & Egypt & $-(60)$ & $3.8(112)$ & $3.4(129)$ & $4.2(73)$ & - & - \\
\hline & Morocco & $-(61)$ & $4.6(64)$ & $4.6(57)$ & $4.0(87)$ & - & - \\
\hline \multirow[t]{3}{*}{ Affordability of financial services } & Tunisia & $-(31)$ & $3.9(87)$ & $3.9(90)$ & $3.3(103)$ & - & - \\
\hline & Egypt & $-(69)$ & $3.7(106)$ & $3.3(126)$ & $3.6(85)$ & - & - \\
\hline & Morocco & $-(56)$ & $4.2(67)$ & $4.2(61)$ & $3.7(76)$ & - & - \\
\hline \multirow{3}{*}{$\begin{array}{l}\text { Ease of access to loans ("financing of } \\
\text { SMEs" reported for } 2018 \& 2019 \text { ) *** }\end{array}$} & Tunisia & $-(30)$ & $2.9(67)$ & $2.8(71)$ & $3.4(104)$ & $3.6(90)$ & $3.4(109)$ \\
\hline & Egypt & $-(49)$ & $2.4(100)$ & $1.9(128)$ & $3.9(66)$ & $3.6(89)$ & $4.3(41)$ \\
\hline & Morocco & $-(44)$ & $2.8(69)$ & $3.1(47)$ & $3.8(77)$ & $3.9(56)$ & $4.0(61)$ \\
\hline \multirow[t]{3}{*}{ Venture capital availability } & Tunisia & $-(21)$ & $3.0(44)$ & $2.3(111)$ & $2.5(100)$ & $2.7(91)$ & $2.7(95)$ \\
\hline & Egypt & $-(41)$ & $2.9(51)$ & $2.5(91)$ & $2.8(74)$ & $2.8(74)$ & $3.1(75)$ \\
\hline & Morocco & $-(40)$ & $2.8(56)$ & $2.7(68)$ & $2.6(90)$ & $2.8(81)$ & $3.0(86)$ \\
\hline \multirow[t]{3}{*}{ Soundness of banks } & Tunisia & $-(59)$ & $3.9(131)$ & $3.2(131)$ & $3.7(117)$ & $3.8(112)$ & $3.7(123)$ \\
\hline & Egypt & $-(61)$ & $4.0(125)$ & $4.8(70)$ & $5.4(49)$ & $5.6(32)$ & $5.9(23)$ \\
\hline & Morocco & $-(69)$ & $5.7(41)$ & $5.2(54)$ & $5.4(48)$ & $5.7(23)$ & $5.7(30)$ \\
\hline
\end{tabular}

Source. Own compilation based on data retrieved from the yearly Global Competitiveness Reports published by the World Economic Forum. 
INSIGHTS INTO REGIONAL DEVELOPMENT

ISSN 2669-0195 (online) http://jssidoi.org/jesi/ 2021 Volume 3 Number 2 (June) http://doi.org/10.9770/IRD.2021.3.2(5)

\section{B. Selected Innovation Indicators}

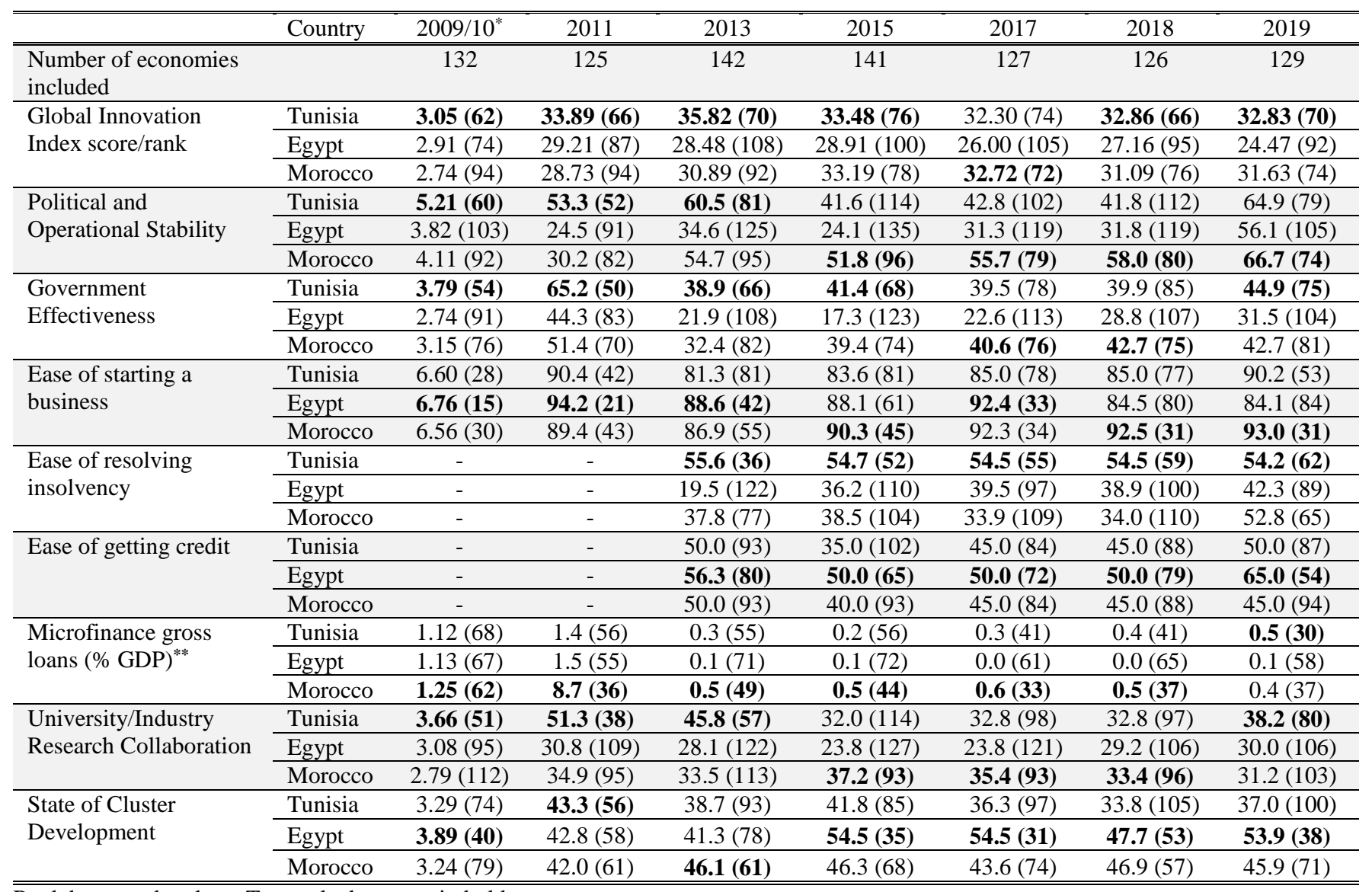

Rank between brackets. Top ranked country in bold.

* The significant difference in scores between 2009/10 and the subsequent years is due to the change of the GII methodology introduced in 2011.

*** Named "Microfinance Institutions (MFIs) -Average loan balance per borrower/GNI per capita" in 2009/10.

Source: Own compilation based on data retrieved from the yearly Global Innovation Index (GII) Reports. 
INSIGHTS INTO REGIONAL DEVELOPMENT

ISSN 2669-0195 (online) http://jssidoi.org/jesi/

2021 Volume 3 Number 2 (June)

http://doi.org/10.9770/IRD.2021.3.2(5)

C. Selected Infrastructure, Education, and Labor Market Indicators

\begin{tabular}{|c|c|c|c|c|c|c|c|}
\hline & Country & $2010 / 11^{*}$ & $2013 / 14$ & $2016 / 17$ & $2017 / 18$ & $2018^{* *}$ & 2019 \\
\hline Number of economies included & & 139 & 148 & 138 & 137 & 140 & 141 \\
\hline \multicolumn{8}{|l|}{ INFRASTRUCTURE } \\
\hline \multirow[t]{3}{*}{ Quality of overall infrastructure } & Tunisia & - (30) & $4.1(80)$ & $3.7(84)$ & $3.7(86)$ & $62.5(84)$ & $62.7(85)$ \\
\hline & Egypt & $-(68)$ & $3.3(118)$ & $3.1(108)$ & $4.0(73)$ & $70.5(56)$ & $73.1(52)$ \\
\hline & Morocco & $-(71)$ & $4.9(48)$ & $4.5(50)$ & $4.7(42)$ & $71.5(53)$ & $72.6(53)$ \\
\hline \multirow[t]{3}{*}{ Quality of roads } & Tunisia & $-(37)$ & $3.8(77)$ & $3.5(87)$ & $3.7(84)$ & $3.8(81)$ & $3.6(96)$ \\
\hline & Egypt & $-(75)$ & $2.7(122)$ & $3.0(107)$ & $3.9(75)$ & $4.5(45)$ & $5.1(28)$ \\
\hline & Morocco & $-(88)$ & $4.5(53)$ & $4.4(55)$ & $4.5(43)$ & $4.5(48)$ & $4.7(41)$ \\
\hline \multirow{3}{*}{$\begin{array}{l}\text { Quality of railroad infrastructure } \\
\text { ("efficiency of train services" reported } \\
\text { for } 2018 \& 2019 \text { ) }\end{array}$} & Tunisia & $-(29)$ & $3.4(49)$ & $2.8(63)$ & $2.8(67)$ & $3.2(70)$ & $3.2(59)$ \\
\hline & Egypt & $-(46)$ & $2.7(63)$ & $2.6(73)$ & $3.3(50)$ & $3.6(58)$ & $3.8(50)$ \\
\hline & Morocco & $-(37)$ & $3.9(37)$ & $3.9(37)$ & $3.9(38)$ & $3.7(55)$ & $3.9(44)$ \\
\hline \multirow{3}{*}{$\begin{array}{l}\text { Quality of port infrastructure } \\
\text { ("efficiency of seaport services" } \\
\text { reported for } 2018 \& 2019 \text { ) }{ }^{* *}\end{array}$} & Tunisia & $-(41)$ & $4.0(82)$ & $3.3(100)$ & $3.3(101)$ & $3.5(88)$ & $3.4(95)$ \\
\hline & Egypt & $-(69)$ & $4.1(80)$ & $4.3(58)$ & $4.7(41)$ & $4.6(39)$ & $4.8(41)$ \\
\hline & Morocco & $-(62)$ & $5.0(41)$ & $4.8(38)$ & $5.0(32)$ & $4.9(28)$ & $5.1(24)$ \\
\hline \multirow{3}{*}{$\begin{array}{l}\text { Quality of air transport infrastructure } \\
\text { ("efficiency of air transport services" } \\
\text { reported for } 2018 \& 2019 \text { ) }\end{array}$} & Tunisia & $-(38)$ & $4.5(67)$ & $3.9(97)$ & $3.9(98)$ & $3.8(102)$ & $3.6(118)$ \\
\hline & Egypt & $-(39)$ & $4.8(59)$ & $4.8(52)$ & $5.1(42)$ & $5.1(43)$ & $5.1(46)$ \\
\hline & Morocco & $-(67)$ & $5.0(49)$ & $4.7(55)$ & $4.8(54)$ & $5.0(46)$ & $5.3(38)$ \\
\hline \multirow[t]{3}{*}{ Quality of electricity supply } & Tunisia & $-(35)$ & $5.3(56)$ & $5.1(60)$ & $5.1(60)$ & $87.3(98)$ & $88.0(98)$ \\
\hline & Egypt & $-(53)$ & $3.4(107)$ & $3.5(102)$ & $5.0(63)$ & $92.4(74)$ & $91.8(77)$ \\
\hline & Morocco & $-(66)$ & $5.5(47)$ & $5.3(53)$ & $5.6(46)$ & $88.3(97)$ & $88.4(97)$ \\
\hline \multirow[t]{3}{*}{ Availability of latest technologies } & Tunisia & $-(42)$ & $4.8(77)$ & $4.6(76)$ & $4.6(76)$ & - & - \\
\hline & Egypt & $-(91)$ & $4.1(117)$ & $3.9(117)$ & $4.3(91)$ & - & - \\
\hline & Morocco & $-(68)$ & $5.0(66)$ & $5.0(50)$ & $5.1(50)$ & - & - \\
\hline \multirow[t]{3}{*}{ Firm-level technology absorption } & Tunisia & $-(33)$ & $4.7(70)$ & $4.1(106)$ & $4.0(111)$ & - & - \\
\hline & Egypt & $-(58)$ & $4.2(110)$ & $3.8(121)$ & $4.1(100)$ & - & - \\
\hline & Morocco & $-(74)$ & $4.4(95)$ & $4.6(63)$ & $4.5(62)$ & - & - \\
\hline \multicolumn{8}{|l|}{ EDUCATION } \\
\hline \multirow{3}{*}{$\begin{array}{l}\text { Quality of the education system } \\
\text { ("skillset of graduates" reported for } \\
2018 \& 2019 \text { ) }\end{array}$} & Tunisia & $-(20)$ & $3.7(71)$ & $3.1(107)$ & $3.1(103)$ & $3.6(103)$ & $3.6(108)$ \\
\hline & Egypt & $-(131)$ & $2.2(145)$ & $2.1(135)$ & $2.5(130)$ & $2.9(136)$ & $3.1(133)$ \\
\hline & Morocco & $-(105)$ & $3.1(110)$ & $2.8(119)$ & $2.7(120)$ & $3.5(117)$ & $3.5(117)$ \\
\hline \multirow{3}{*}{$\begin{array}{l}\text { Quality of primary education ("pupil-to- } \\
\text { teacher ratio in primary education" } \\
\text { reported for } 2018 \& 2019 \text { ) }\end{array}$} & Tunisia & $-(22)$ & $3.9(72)$ & $3.6(85)$ & $3.7(83)$ & $16.2(51)$ & $16.2(55)$ \\
\hline & Egypt & $-(126)$ & $2.0(148)$ & $2.1(134)$ & $2.4(133)$ & $23.1(86)$ & $23.8(89)$ \\
\hline & Morocco & $-(100)$ & $2.9(118)$ & $2.9(118)$ & $2.8(119)$ & $26.6(95)$ & $28.0(102)$ \\
\hline \multirow{3}{*}{$\begin{array}{l}\text { Quality of math and science education } \\
\text { ("critical thinking in teaching" reported } \\
\text { for } 2018 \& 2019 \text { ) }\end{array}$} & Tunisia & $-(8)$ & $4.7(31)$ & $4.4(57)$ & $4.6(44)$ & $3.1(94)$ & $3.1(99)$ \\
\hline & Egypt & $-(125)$ & $2.2(145)$ & $2.6(130)$ & $2.8(122)$ & $2.6(123)$ & $2.7(123)$ \\
\hline & Morocco & $-(67)$ & $4.3(52)$ & $4.0(72)$ & $3.8(80)$ & $2.2(138)$ & $2.7(121)$ \\
\hline \multirow{3}{*}{ Quality of management schools } & Tunisia & $-(22)$ & $4.3(66)$ & $4.1(78)$ & $4.0(83)$ & - & - \\
\hline & Egypt & $-(122)$ & $2.3(145)$ & $2.5(138)$ & $3.2(124)$ & - & - \\
\hline & Morocco & $-(49)$ & $4.6(45)$ & $4.1(76)$ & $4.0(86)$ & - & - \\
\hline \multirow{3}{*}{$\begin{array}{l}\text { Quality of scientific research institutions } \\
\text { ("research institutions prominence" } \\
\text { reported for } 2018 \& 2019 \text { ) }\end{array}$} & Tunisia & - (38) & $3.3(94)$ & $3.2(111)$ & $3.3(96)$ & $5.2(52)$ & $4.4(57)$ \\
\hline & Egypt & $-(110)$ & 2.7 (127) & $2.6(128)$ & $2.8(121)$ & $15.3(32)$ & $14.8(37)$ \\
\hline & Morocco & $-(93)$ & $3.2(103)$ & $3.1(112)$ & $3.0(111)$ & $5.8(50)$ & $5.9(53)$ \\
\hline \multirow{3}{*}{$\begin{array}{l}\text { Primary education enrollment rate, net } \\
\%\end{array}$} & Tunisia & $-(33)$ & $99.4(14)$ & $98.6(21)$ & $98.6(24)$ & - & - \\
\hline & Egypt & $-(73)$ & $95.6(58)$ & $98.0(28)$ & $98.0(33)$ & - & - \\
\hline & Morocco & $-(99)$ & $96.0(54)$ & $98.4(22)$ & $98.4(26)$ & - & - \\
\hline \multirow{3}{*}{$\begin{array}{l}\text { Secondary education enrollment rate, } \\
\text { gross } \%\end{array}$} & Tunisia & $-(53)$ & $92.6(59)$ & $87.6(82)$ & $88.2(81)$ & - & - \\
\hline & Egypt & $-(90)$ & $72.5(102)$ & $86.1(85)$ & $86.1(84)$ & - & - \\
\hline & Morocco & $-(110)$ & $69.8(103)$ & $69.1(101)$ & $69.1(100)$ & - & - \\
\hline \multirow{3}{*}{$\begin{array}{l}\text { Tertiary education enrollment rate, gross } \\
\%\end{array}$} & Tunisia & $-(69)$ & $37.1(71)$ & $34.6(79)$ & $34.6(79)$ & - & - \\
\hline & Egypt & $-(78)$ & $27.8(82)$ & $31.7(81)$ & $36.2(76)$ & - & - \\
\hline & Morocco & $-(102)$ & $14.1(106)$ & $24.6(92)$ & $28.1(85)$ & - & - \\
\hline
\end{tabular}


INSIGHTS INTO REGIONAL DEVELOPMENT

ISSN 2669-0195 (online) http://jssidoi.org/jesi/

2021 Volume 3 Number 2 (June)

http://doi.org/10.9770/IRD.2021.3.2(5)

\begin{tabular}{|c|c|c|c|c|c|c|c|}
\hline \multicolumn{8}{|l|}{ LABOR MARKET } \\
\hline \multirow[t]{3}{*}{ Hiring and firing practices } & Tunisia & $-(52)$ & $3.5(105)$ & $2.8(126)$ & $2.7(130)$ & $2.9(129)$ & $3.0(126)$ \\
\hline & Egypt & $-(76)$ & $3.3(120)$ & $3.9(61)$ & $3.7(70)$ & $4.0(51)$ & $3.9(63)$ \\
\hline & Morocco & $-(66)$ & $3.7(93)$ & $3.3(103)$ & $3.3(109)$ & $3.4(103)$ & $3.8(73)$ \\
\hline \multirow[t]{3}{*}{ Pay and productivity } & Tunisia & $-(52)$ & $3.5(108)$ & $3.0(132)$ & $3.1(126)$ & $3.2(124)$ & $3.2(127)$ \\
\hline & Egypt & $-(76)$ & $3.1(131)$ & $3.2(125)$ & $3.4(107)$ & $3.8(75)$ & $4.2(58)$ \\
\hline & Morocco & $-(50)$ & $4.0(67)$ & $3.4(114)$ & $3.6(96)$ & $3.6(87)$ & $3.7(85)$ \\
\hline \multirow[t]{3}{*}{ Reliance on professional management } & Tunisia & $-(40)$ & $3.9(98)$ & $3.8(94)$ & $3.9(88)$ & $3.9(88)$ & $3.9(104)$ \\
\hline & Egypt & $-(86)$ & $3.1(137)$ & $3.1(133)$ & $3.9(92)$ & $4.0(82)$ & $4.1(91)$ \\
\hline & Morocco & $-(105)$ & $4.0(90)$ & $4.0(84)$ & $4.0(79)$ & $4.2(66)$ & $4.5(58)$ \\
\hline \multirow{3}{*}{$\begin{array}{l}\text { Country capacity to retain talent ("ease } \\
\text { of finding skilled employees" reported } \\
\text { for } 2018 \& 2019 \text { ) } \text { *ै* }^{*}\end{array}$} & Tunisia & $-(42)$ & $3.4(74)$ & $2.8(110)$ & $2.7(111)$ & $4.2(66)$ & $4.0(88)$ \\
\hline & Egypt & $-(114)$ & $2.3(133)$ & $2.9(104)$ & $2.9(103)$ & $3.6(109)$ & $4.0(87)$ \\
\hline & Morocco & $-(76)$ & $3.6(54)$ & $3.2(91)$ & $3.2(90)$ & 3.8 (99) & $4.0(94)$ \\
\hline
\end{tabular}

Source: Own compilation based on data retrieved from the yearly Global Competitiveness Reports published by the World Economic Forum.

Nizar BECHEIKH is Associate Professor of Strategy and Innovation Management and former Dean at the School of Business of the American University in Cairo (AUC, Egypt). He earned a Ph.D. in Business Administration and a MBA in International Management from Laval University (Canada). His current research interests focus on political economy in the Arab region, innovation paths and best practices in developing countries, and managing growth and innovation in small and medium-sized enterprises in Arab countries.

ORCID ID: orcid.org/0000-0002-4572-1675

Make your research more visible, join the Twitter account of INSIGHTS INTO REGIONAL DEVELOPMENT:

@IntoInsights

Copyright (C) 2021 by author(s) and VsI Entrepreneurship and Sustainability Center

This work is licensed under the Creative Commons Attribution International License (CC BY).

http://creativecommons.org/licenses/by/4.0/

(c) (i) Open Access 